\title{
Industrial Development and Transformation: Insights from Outstanding Cases
}

Industrial policy and economic transformation have been attracting renewed attention in recent years. Several studies in the past decade or so have focused on industrial developmentespecially industrial structure upgrading and diversification-as a basis for sustained economic growth and development.

These studies have emphasized such aspects as the accumulation of knowledge and capabilities and the creation of a learning society (Cimoli et al. 2009; Stiglitz and Greenwald 2014); the exploiting and changing endowments and comparative advantage (Lin 2012); the need to compensate for information externalities generated by pioneer firms (Rodrik 2007); and pragmatic policymaking for developing countries that must cope with the strong pressures of market orientation and globalization in our times (Ohno 2013).

The main objective of this chapter is to obtain insights into how these crucial factors interact in practice, focusing on five outstanding cases of what we call "industrial strategy" that resulted in a remarkable economic transformation in a country or in regions of a country. These five cases are: (1) the automobile industry in Thailand; (2) the transformation of the "Cerrado" in Brazil from barren lands to a source of highproductivity agriculture; (3) the garment industry in Bangladesh; (4) the salmon farming and processing industry in Chile; and (5) the upgrading of Singapore's industrial sector from labor to knowledge-intensive. These case studies, which are the main focus of this chapter, can be found below in the section titled "Case Studies."

As these five cases suggest, we use the terms "industry" and "industrial sector" very broadly to refer not only to the manufacturing sector but also agro-business, modern agriculture, aquaculture, transport, logistics, tourism, and any other activities that produce nontraditional or "modern" goods and services that require significant human and/or physical capital. Similarly, industrial strategy refers not only to narrowly defined "industrial policy" targeted at manufacturing, but also other policy areas, such as education policy, fiscal policy, financial policy, trade policy, and labor policy, which encourage the development of the aforementioned productive activities $^{1}$.

The next section briefly reviews the major findings of some recent studies related to industrial policy and economic transformation and outlines the analytical perspective of this chapter. This is followed by the case studies. Finally, the concluding section attempts to extract lessons that could be derived from these cases. In the Further Discussion section, I will examine the insights and implications that can be derived from the case studies presented in this chapter in regard to the catalytic role of international cooperation for industrial development and transformation. 


\subsection{An Analytical Perspective}

Major Findings of Recent Studies Related to Industrial Strategy and Economic Transformation.

\subsubsection{Change of Endowments and Dynamic Comparative Advantage: The Focus of Industrial Strategy}

As discussed in Chap. 2, quality of growth needs to be considered in the context of changing endowments and transformation. This is because industrial transformation is a driver of growth and could be related to different attributes of growth. As such, industrial strategy needs to address enhancement of endowments including, among other aspects, infrastructure, human capital, social capital, natural capital, financial capital, institutions, and learning capacity related to the accumulation of knowledge and capabilities. It needs to catalyze or facilitate industrial transformation, taking full advantage of changing endowments, through creation of new industries, deepening of value chains, diversification, and so on. Industrial strategy also needs to attain the desired attributes of quality growth in the process of industrial transformation. In sum, the nexus between changing endowments, industrial transformation, and quality growth needs to be the main focus of an industrial strategy.

Now, in this nexus, changing of endowments are essential for attaining dynamic comparative advantage, which is intimately related to new industries and industrial transformation. According to Noman and Stiglitz (2012), the "old" policies focused on improving economic efficiency within a static framework: "But the essence of development is dynamic. What matters, for instance, is not comparative advantage as of today, but dynamic comparative advantage" (7). JICA and JBIC (2008, 48-55) review some cases of the industrial development of Asian countries through "developing new comparative advantage." This concept of new comparative advantage appears to be similar to dynamic comparative advantage.

Lin (2012), while discussing the "changing comparative advantage," argues that "The more effective route for their learning and development is to exploit the advantages of backwardness and upgrade and diversify into new industries according to the changing comparative advantages determined by the changes in their endowment structure" (73).

Lin goes on to explain, "Conceptually, it is useful to add infrastructure as one more component in an economy's endowments. Infrastructure includes hard infrastructure and soft infrastructure" (22). The new structural economics, which he advocates, "considers human capital to be one component of a country's endowment" (36). Here it should be underlined that several components are endogenous. It includes infrastructure and the human capital in which learning capacity is embedded. These are crucial in changing comparative advantage.

In addition, we should emphasize the fundamental differences between "hard infrastructure" and "soft infrastructure" in this context. First, while the former (roads, ports, airports, energy plants, and so on) can be realized through intensive investments in a relatively short period, the latter is achieved only through a longer-term, incremental process, and is essentially path dependent. Second, investments in learning are high risk, and risk markets are absent (especially in developing countries), which also discourages such investments (Greenwald and Stiglitz 2012, 6). Moreover, the feasibility and rate of return of investments in hard infrastructure can be measured. Nevertheless, both soft infrastructure and hard infrastructure tend to have a public good dimension and, as Greenwald and Stiglitz (2012) argue, "markets by themselves are never efficient in the production and utilization of public goods" (5).

In Chap. 2, I highlighted learning capacity (and human capital in which learning capacity is embedded), infrastructure, and institutions as essential endowments for industrial transformation. In the next sub-section, I will discuss how countries enhance and change these endowments. 


\subsubsection{Leading Industries, Economic Transformation, and the Role of Government and Institutions}

Now two basic questions need to be answered in this context: How and under what conditions do countries change endowments? How and under what conditions do countries take advantage of a changing comparative advantage to develop new industries? Endowments could be changed dynamically. As soft and hard infrastructuresimportant components of endowments of a country - are endogenous and essentially public goods, and as the market is often not efficient in the production and utilization of public goods, government and/or public and private institutions have to play an important role in the dynamic change of endowments.

The Commission on Growth and Development's Report (2008) studied the experience of thirteen countries that had achieved annual growth rates of $7 \%$ or more for at least twentyfive years. The report identified having "committed, credible, and capable governments" as one of five characteristics of high-performing countries. These governments, except for that of Hong Kong, were more hands-on, intervening with tax breaks, subsidized credit, directed lending, and other such measures. These interventions may have helped them to discover their comparative advantage (Noman and Stiglitz 2012, 12).

However, the role of governments referred to by the Growth Commission's report is basically related to the static comparative advantage of countries. Rodrik's (2007) view on "selfdiscovery" can likewise be said to bear mainly on static comparative advantage. As the dynamic change of endowments that transforms long-term comparative advantage is endogenous, the governments also have an important role to play in relation to dynamic comparative advantage. Noman and Stiglitz (2012, 12 and note 15) refer to this point. In short, the government's role is twofold: (1) facilitating "self-discovery" of static comparative advantage and (2) investing in learning and soft and hard infrastructures that are endogenous components of endowments for dynamic (long-term) comparative advantage.

This chapter's objective is to generate insights into both of these aspects, but with special reference to the second aspect, based on case studies of countries that were able to realize outstanding economic transformation rather than just high performance in terms of growth. I will focus on (1) how endowments dynamically changed in terms of hard and soft infrastructures; (2) how investment in hard infrastructure was made and how learning, as well as the accumulation of knowledge and capabilities, was achieved; (3) how the transformation was triggered (initiated) with the change of endowments; (4) what kind of drivers (driving forces) kept the momentum of transformation; and (5) what kind of strategy/vision was behind the process and what policies and institutions promoted it.

The World Bank $(2012,218)$ summarizes the current discussion on "industrial policy," highlighting three schools of thought: (a) new structural economics; (b) an approach that emphasizes the policy process and especially a public-private partnership; and (c) a school of thought that stresses spillovers of productive knowledgemastering ways of doing things. The document cites views of opponents regarding, among others, the practicality of implementing such a policy, doubting especially whether the public sector has the capacity to identify industries with potentially sizable knowledge spillovers and dynamic scale economies.

This chapter addresses basic questions of the "industrial strategy and economic transformation agenda" focusing on the five aspects discussed in this section. This will also provide some insights into aspects of the controversy among the three schools of thought, as well as the opposing arguments.

\subsubsection{Typology of Industrial Development and Transformation Challenges}

Challenges facing countries differ as they move along the development path, with new challenges 
emerging and endowments changing. Industrial development strategies could be different depending on the challenges that countries face. Countries may focus in different ways on infrastructure, human resource development, technological innovation, or other investments. In some countries, industrial challenges are shaped by special circumstances affecting particular groups such as resource-rich countries, small countries, and post-conflict countries ${ }^{2}$.

A typological approach could be useful in addressing these diversities. JICA and JBIC (2008) distinguish, first of all, resource-rich countries and resource-poor countries. The World Bank (2012) identifies eight categories of "job challenge," including resource-rich countries, urbanizing countries, and conflict-affected countries.

From the point of view of the "economic transformation agenda," meaningful categorization could be accomplished according to the endowments of almost-fixed or exogenous factors such as mineral and energy resources on the one hand. On the other hand, meaningful categorization could result from the endowment of endogenous factors such as hard and soft infrastructure. With regard to the former type of endowments, we need to introduce the two categories of resource-rich countries and resourcepoor countries. For the latter we need to take into account the development phases reflecting human resource development as well as physical infrastructure endowment such as (1) agrarian countries, (2) urbanizing and early industrializing countries dependent on labor-intensive sectors, (3) industrializing countries with higher skills and technology, and (4) countries with high-level technological and innovative capabilities.

These categories are not mutually exclusive and might not cover all types of divergence among countries. Having this endowments-based categorization in mind, three resource-poor Asian countries in different phases of developmentBangladesh, Thailand, and Singapore-were selected. From Latin America, two resource-rich countries were also included: Brazil and Chile. All of the selected countries have been at least fairly high-performing countries for roughly two decades.

\subsubsection{Research Questions for Case Studies}

Based on the research questions set out on page 41 , the most important questions to be answered in the case studies of selected countries are how economic transformation was achieved with endowment changes, and how such endowment changes were attained. More concretely, the case studies examine how learning and accumulation of knowledge and capabilities took place, how hard infrastructure was constructed, and what kinds of policies and institutions enabled the process of change and transformation. These practical aspects need to be analyzed in order to obtain insights into successful industrial strategies with impacts on economic transformation.

As mentioned earlier, how the transformation process was triggered (initiated) with the change of endowments and what kind of drivers (driving forces) maintained the momentum of transformation are important research questions as well.

\subsection{Case Studies}

\subsubsection{Case 3.1: Thailand's Automobile Industry}

In 1995, Thailand's annual automobile exports were less than half a billion U.S. dollars, well below exports from India and Malaysia. By 2008, exports approached twenty-eight billion U. S. dollars, making Thailand the largest automobile exporter in the Association of Southeast Asian Nations (ASEAN) region, the third-largest in Asia, after Japan and South Korea, and the seventh-largest exporter in the world. Production reached 1 million cars in 2005 and 2.5 million cars in 2012. Automobile assembly and autoparts industries account for more than $10 \%$ of the GDP of the country and employ approximately 1 million people. 
It is estimated that as of 2010 there were about 690 first-tier parts makers, $30 \%$ of them Thai majority joint venture companies, $23 \%$ of them pure Thai companies, and 1700 second- and thirdtier parts makers, most of them locally owned small and medium enterprises (SMEs) supporting the automobile industry in Thailand (Natsuda and Thoburn 2011, 8). As such, "Thailand is not a country where carmakers assemble their products. Most parts come from local companies. At more than $80 \%$, the country has the highest localization in South East Asia.... Thailand also exports parts worth about $\$ 5$ billion" (T. J. 2013). At present, the automobile industry is the principal engine for growth in Thailand's economy. "The Detroit of Asia" envisaged once by the Thai government is now a reality and the "automobile belt" has been established from Ayutthaya to the Eastern Seaboard.

\subsubsection{Accumulation of Knowledge and Capabilities, Prerequisite for Development of an Automobile Industry}

As Athukorala and Kohpaiboon (2011) argue, "The automobile industry has been the target of industrial development in many countries as a growth driver - a source of employment, technological expertise, and a stimulus to other sectors through backward linkages.... But only a handful of developing countries have managed to develop an internationally competitive automobile industry" 3 .

Development of an automobile industry requires skilled labor and supporting industries to provide twenty to thirty thousand parts and components. Supporting industries and automobile assembly plants are closely related and provide externality to each other. Accordingly, in many countries, the lack of supporting industries made the installation of automobile assembly plants difficult, while supporting industries were constrained by the demand for parts and components of assembly plants, a clear chicken and egg conundrum. Furthermore, the development of supporting industries for automobile industries takes years because they need a prolonged process of accumulation of knowledge and capabilities, especially the formation of human resources and learning about technology.

Among several policy measures, a series of initiatives by the Thai government to incrementally enhance the localization of parts production was important for the accumulation of knowledge and capabilities of supporting industries. In the 1960 s, the board of investment (BOI) introduced the Industrial Investment Promotion Act, and with Thai capital, six major foreign automobile joint ventures were established by the end of the decade. However, the production of vehicles remained very limited, accounting for only $18.5 \%$ of the total sales of automobiles in the country in 1969, and the process depended heavily on assembly operations using imported completely knocked down (CKD) kits that created a serious imbalance of trade and payment deficits (Natsuda and Thoburn 2011, 13).

The specific policies for the automobile industry, introduced for the first time in 1971, established, among others, a local content requirement (LCR) of $25 \%$, which became effective in 1973, and conditions for new market entry of over 0.2 million baht for investment (except for land). There was also a production capacity of 30 units per day in order to achieve economies of scale- essential for competitive development in the automobile industry ${ }^{4}$. The LCR encouraged car assemblers to produce locally or to purchase parts from local companies. This was not easy because the supporting industries in Thailand did not exist. Assembling companies had to start the process of localization from scratch. Following this, the LCR was raised incrementally through 1994 up to $60 \%$ for pickup trucks with gasoline engines and $72 \%$ for those with diesel engines. The LCR was abolished in 2000 in consideration of WTO rules ${ }^{5}$.

Techakanont (2008) considers that "the most important policy of the Thai state was the implementation of the LCR" (8). In order to comply with the LCR, automobile assembly companies in Thailand had to increase the local 
content of components that they produced themselves, ask their component suppliers in their countries of origin to invest in Thailand, or support local Thai firms to produce components with the required quality standards. Based on his extensive field research, Yamashita (2004) concludes that "the process of adapting to the LCR enabled the accumulation of a very wide range of automobile parts industries and the training of skilled technicians and engineers, both of which are indispensable for the development of the automobile industry" $(5)^{6}$. Through this process, assembly companies have offered continuous technological support to local supporting industries.

In this context, it should be emphasized that "most of the policies in the early 1980s were deliberated in a formal public-private cooperation committee (PPCC) before they were officially declared as government policy" (Techakanont 2008, 12). Doner (1991) explains: "The policy makers were quite flexible for assemblers to choose how to produce parts: either produce them locally or assemble compo-

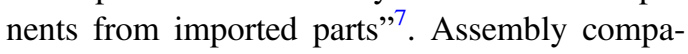
nies asked the Thai government to revise the LCR policy when they reached the $54 \%$ level because any further increase of the LCR percentage would make it difficult to assure the safety of the cars and further reduce the cost of production. Responding to this request, the government switched its policy from the LCR to one requiring the local production of specific important components such as engines (Techakanont 2008, 9).

\subsubsection{Formation of Automobile Clusters and Industrial Estates}

The government facilitated the formation of industrial clusters by establishing the infrastructure for manufacturing activities, especially automobile assembly and parts production. Automakers and their components suppliers enhanced their competitiveness when they were agglomerated as a cluster with articulated value chains.
For this purpose, the Industrial Estate Authority of Thailand (IEAT) was established in 1972 and many industrial estates (IEs) were constructed, firstly around Bangkok and later on the Eastern Seaboard and its vicinities. The agglomeration of assemblers and part makers in IEs began in the 1970s. The establishment of IEs, leading to cluster formations, has been an important instrument through which the Thai government attracts foreign investors by providing infrastructure and tax incentives (Lecler 2002, 802).

\subsubsection{Eastern Seaboard: Infrastructure that Triggered the Rapid Expansion of Thailand's Automobile Industry}

The automobile industry requires efficient ports and logistics facilities in order to be competitive in the export market. From this perspective, the most important milestone for Thailand's automobile industry was the construction of infrastructure on the Eastern Seaboard.

The development of this infrastructure created an export hub and the center for technologyintensive industries: 14 industrial estates, 360,000 workers, 1300 factories, and 516 automobile-related factories. The explosive emergence and concentration of new machinery and metal and non-metal industries with FDI inflows in the early 1990s, which occurred around Leam Chabang, became possible only through the completion of such large-sized infrastructure as the Eastern Seaboard Development Plan, which became a synergetic production nexus and a hub for the shipment of products (Shimomura and Mieno 2008, 14-16).

The Eastern Seaboard Development Plan is a leading large-scale development scheme that the Thai government implemented in the 1980s with assistance from Japan and the World Bank. It had the twofold purpose of boosting international strength and inviting direct overseas investment in export-oriented industrial fields, and easing the over-concentration of economic activity in Bangkok. The large-scale project, which extends 
over three provinces in the coastal area southeast of Bangkok, consists of a composite industrial site formed by two deep sea ports, Leam Chabang and Map Ta Put, supported by harbors, roads, railways, dams, service pipelines, and other facilities ${ }^{8}$.

Today, Leam Chabang, Thailand's largest port, plays a significant part in increasing trade in Thailand and is home to a heavy concentration of Thailand's automobile industry, with many automakers' and parts manufacturers' operations set up in the area. In 2013, the Eastern Seaboard region accounted for $16 \%$ of Thailand's GDP, making it, along with the Bangkok metropolitan area, a key source of the country's economic strength (The Japan Journal 2014, 7). Figure 3.1 illustrates how these activities have moved into the Eastern Seaboard and demonstrates that this infrastructure produced a major change in the endowments' structure in Thailand, playing a crucial role in this country becoming the "Detroit of Asia."

\subsubsection{4 "Detroit of Asia" Vision}

The Thai automobile industry experienced different phases of development, namely the introduction of the localization policy (1971-1977), the strengthening of localization capacity (19781990), and liberalization (1991-1999) (Natsuda and Thoburn 2011, 13-20). A new phase started after the Thai government abolished the LCR in 2000 and introduced the New Automobile Investment Policy in 2002, which aimed to develop Thailand into a regional center of the automobile industry in Southeast Asia. Two years later, a further automobile development plan was introduced, the so-called Detroit of Asia plan, which was later renamed the "Production of Asia" plan (22). However, the government's first "product champion," the pickup truck, was considered insufficient to meet the targets of this plan by 2016 . To attract additional foreign investment from automobile producers, the "Eco Car" project was introduced as the second "product champion" in 2007 (23). At the same time, a

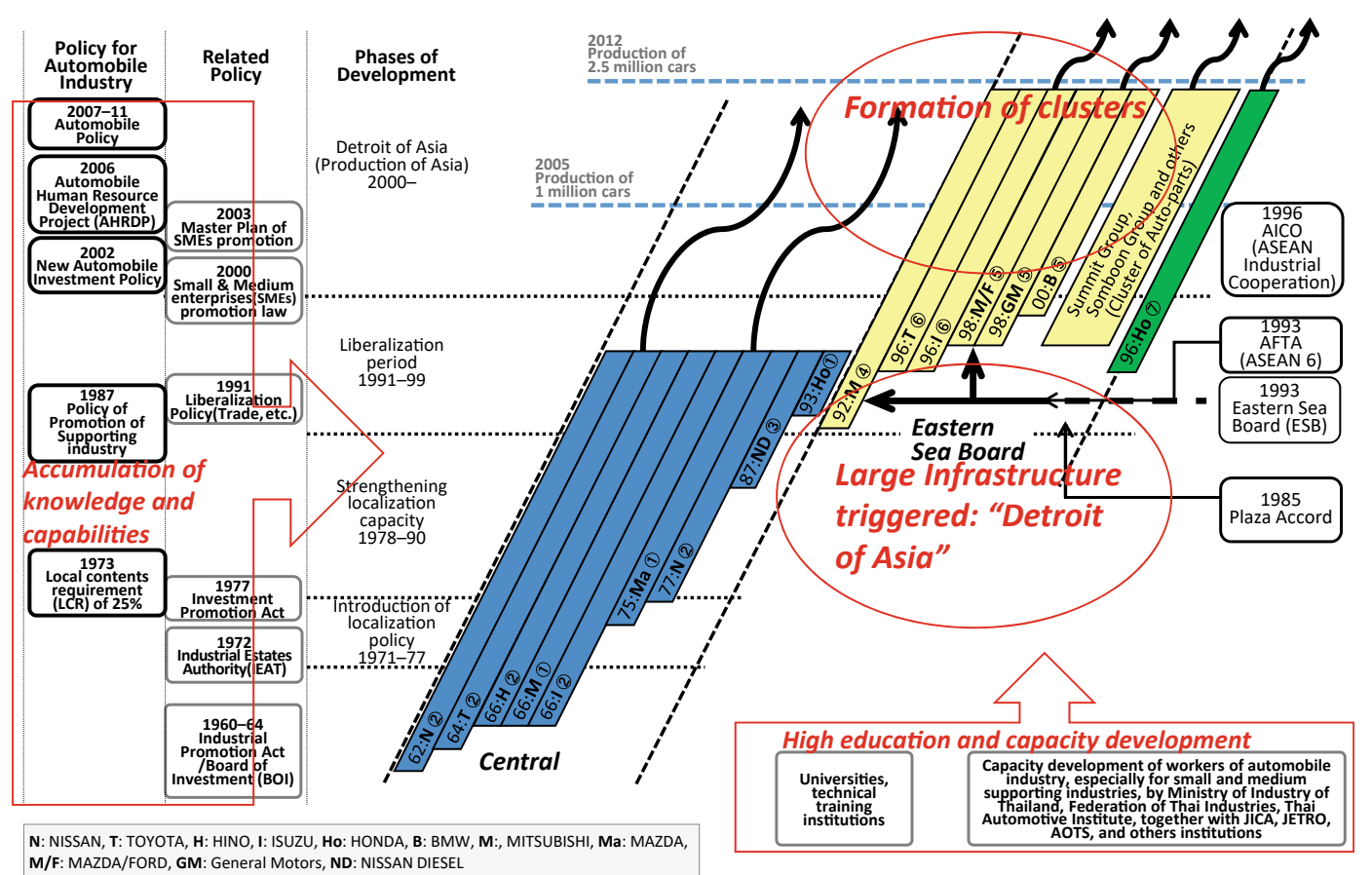

Fig. 3.1 Development of Automobile Industry in Thailand 
policy to strengthen supporting industries through the promotion of SMEs was established: the SMEs promotion law of 2000 and the Master Plan of SMEs promotion of 2003. In addition, the Automotive Human Resource Development Project (AHRDP) was launched in 2006.

\subsubsection{Institutions that Facilitated Changes of Endowments}

There are two public institutions, among others, that have contributed to the development of Thailand's automobile industry. One is the Automobile Development Committee and the other is the Eastern Seaboard Development Committee (ESDC), a cabinet-level national committee chaired by the prime minister together with the Office of ESDC (OESD).

The Automobile Development Committee provided an effective institutional setting for mid-level and senior officials to formulate policies in consultation with firms and business organizations. Interference by political leaders and top-level policymakers was virtually absent in the decision-making process (Athukorala and Kohpaiboon 2011, 12). Thai authorities adopted a consensual and pragmatic approach to setting the LCR target in consultation with automakers, as mentioned earlier. Athukorala and Kohpaiboon highlight that the consensual approach to policymaking and the absence of abrupt policy shifts created stable expectations and confidence in the overall business environment.

Evaluating the Eastern Seaboard, JICA/JBIC (2008, 51) states:

\footnotetext{
The reasons behind the success of the Thai government's plans for the Eastern Seaboard Development are (1) the consistent skill level of the technocrats and their independence from politics; (2) the unique checks and balances structure in Thailand (several players sharing influence means that mutual checks are continuous); (3) the development-centered orientation of the Prem administration, and (4) "the unintended transparent and open political process" created by the intervention of the media 9 .
}

\subsubsection{Other Factors}

In addition to the factors that enabled the outstanding development of the automobile industry of Thailand, we should include the advancement of economic integration among ASEAN countries via the ASEAN Free Trade Area (AFTA), ASEAN Industrial Cooperation (AICO) and other initiatives, and the size of the country's automobile market (the largest among ASEAN countries).

\subsubsection{Summary of the Industrial Development Process}

Figure 3.1 roughly illustrates the development of the automobile industry in Thailand. It details investments by global automobile companies in chronological order, indicating the year of each company's investment. Characteristics of different phases of the development process are shown together with relevant policies of each phase (left-hand side). The construction of infrastructure in the Eastern Seaboard, the establishment of the ASEAN Free Trade Area (AFTA), and other initiatives triggered investments in the Eastern Seaboard and other zones outside of Bangkok, further accelerating the development process.

\subsubsection{Challenges Toward Further Transformation}

As discussed above Thailand achieved a remarkable transformation by establishing a competitive automobile industry. However, the country needs a further transformation to overcome the middle-income trap and become a highincome country. From this perspective, the Thai government's program for Thailand 4.0 (Industry 4.0) deserves special attention. It is a comprehensive package, encompassing infrastructure plans, new policies and institutions, including incentives and facilitation, as well as regional and urban development. For the program, the Thai government has placed the top priority on development of the Eastern Economic Corridor (EEC), comprising the three provinces of Chachoengsao, Chonburi, and Rayong, in the hinterland of the Eastern Seaboard. A new institution, EEC Office, which is expected to accomplish the role of ESDC/OESD for Eastern Seaboard, has been established. 
The program focuses on ten promising industrial sectors: (1) Next-generation cars (electric vehicles, EV; plug-in hybrid vehicles, PHEV and others); (2) Robotics for industry; (3) Smart electronics; (4) Digital technology; (5) Biofuels and biochemicals; (6) Logistics and aviation; (7) Affluent, medical, and wellness tourism; (8) Medical services; (9) Agriculture and biotechnology; and (10) Food products. SMEs, local industry development, and ecofriendly industry development are also prioritized in the program. Six major infrastructure projects for the development of the EEC are: U-Tapao airport; Bangkok-Rayong high-speed railway; double-track railway; Pattaya to U-Tapao motorway; Map Ta Phut Deep Sea Port; and Laem Chabang commercial port.

It appears that the program will take advantage of what has been achieved so far in previous programs, including the Eastern Seaboard Development and automobile industry development. Infrastructure, human resources with advanced learning capacity, and institutions that have been constructed, enhanced, and consolidated through these programs are now important endowments for the dynamic comparative advantage of Thailand and are critical for its program of further transformation.

\subsubsection{Case 3.2: Cerrado Agriculture and Agro-Industry Value Chains in Brazil}

Starting in the mid-1970s, the tropical savanna of Brazil, called the Cerrado, was transformed into one of the world's most productive graingrowing regions in just a quarter of a century, realizing modern upland farming in a tropical region for the first time in human history ${ }^{10}$. This remarkable transformation has become known throughout the world as the "Cerrado Miracle" (Economist 2010). Today, Brazil is one of the world's major grain-producing countries, and in 2012 exported the world's largest volume of soybeans. In 1975, the Cerrado region produced just over 8 million tons of grain, but by 2015, the region was producing 100 million tons of grain, which accounts for about $55 \%$ of domestic production. The agricultural trade surplus for Brazil in FY2013 reached US $\$ 82.9$ billion, far surpassing that of the United States, which stood at US\$40.1 billion (Mizobe 2019, 97).

Dr. Norman E. Borlaug, who received the Nobel Peace Prize for his work related to the green revolution, rated the development of agriculture in the Cerrado as one of the great achievements of agricultural science in the twentieth century. The World Food Prize, founded by Borlaug, was awarded in 2006 to the two Brazilians who contributed most to Cerrado agriculture. This agricultural transformation not only increased the production of competitive commodities such as soybeans, corn, coffee, sugar, and cotton, but also enabled the development of food value chains both inside and outside the Cerrado region. While the production of broiler chicken and pork had been growing steadily in the 1990s, this growth accelerated at the end of the decade, with a sharp increase in meat exports.

The Portuguese word cerrado refers to "closed" land, or land that was for many years regarded as unfit for agriculture. The total area of this vast region is about 240 million hectares, or 5.5 times the land area of Japan. This land was considered to be unsuitable for agriculture because the soil has extremely high acidity, lacks potassium and phosphoric acid, and contains large amounts of aluminum, all of which hinder crop growth.

\subsubsection{Change of Endowment by Technological Innovation, Achieving "A New Comparative Advantage"}

For the development of Cerrado agriculture, three technological aspects appear to have been essential. First, soil improvement and the development of new crop varieties suited to the tropical zone were crucial. These constituted the core technological innovations needed to launch Cerrado agriculture from a base of practically 
zero. Second, the effective dissemination of new technologies and practices to an increasing number of farmers who were the main actors in Cerrado agriculture was necessary. This was because this new industry was undertaken by a large number of farmers and enterprises instead of a limited number of companies, as is the case in some manufacturing industries. Third, a solid and highly effective system was indispensable to continue achieving the technological innovations required for Cerrado agriculture.

The vast land of the Cerrado had a drastic value change, which produced a "new comparative advantage" as defined by the JICA and JBIC study (2008). Here technological innovation was crucial, but the inland transport infrastructure built before and after the transfer of the national capital from Rio de Janeiro to Brasilia, located in the center of the Cerrado, may have been another factor.

The Brazilian government "invested in learning," to borrow a term from Noman and Stiglitz (2012). However, as emphasized earlier, investments in learning are highly risky, and risk markets are normally absent in developing countries. Therefore such investments are discouraged (Noman and Stiglitz 2012, 6). For Cerrado agricultural development, the government took the initiative. The Brazilian Agricultural Research Corporation (EMBRAPA) and its Cerrado Agricultural Research Center (CPAC) were established in 1973 and 1974, respectively, and did in fact achieve a lot of innovations: recent discussions on the Cerrado point out that EMBRAPA's greatest contributions were soil improvement in the Cerrado and breeding improvements in soybeans and other crops. In particular, success in developing new varieties of soybeans that were fit for the tropical climate was a significant technological breakthrough.

Soybeans, a crop suited to temperate regions, bloom and sprout by sensing differences in day length (photoperiod), and soybean cultivation was therefore difficult in the tropical region. Cultivation is even more difficult in lowerlatitude areas in the Cerrado because the day length is nearly constant year-round. Dr. Plínio
Itamar de Mello de Souza developed the revolutionary varieties of soybeans suited to the tropical region. Dr. de Mello collected three thousand soybean varieties from the southern United States, the Philippines, Japan, and other parts of the world, chose those with low sensitivity to changes in day length, then selected those that grow tall in tropical regions and crossbred them with varieties with high yields. Finally, in 1980, the first new soybean variety was ready for cultivation in the Cerrado.

Soybean varieties adapted to tropical zones were essential not only as a new crop, but also for soil improvement in the Cerrado. Soybeans fix nitrogen in the soil through root nodule bacteria and facilitate the absorption of fertilizers in the soil. Therefore, soybeans paved the way for other plants to be introduced to the Cerrado.

\subsubsection{Accumulation of Knowledge and Capabilities}

Although the technology for Cerrado was developed from scratch, there had been years of efforts to establish Cerrado agriculture, beginning even before the establishment of EMBRAPA. Initiatives of farmers with experience in the southern region outside of the Cerrado were crucial as well. They undertook pioneering experimental work in the Minas Gerais Cerrado region. Drawing on their experience, the Program of Guided Settlement of Alto Paranaiba (PADAP) was implemented by the state of Minas Gerais together with the Cooperative Cotia. It was the first structured program to prove the feasibility (for business development) of Cerrado agriculture. The starting point was São Gotardo, in the state of Minas Gerais, in 1974.

In 1975, in its efforts to prepare systems for Cerrado development, the Brazilian government formulated the Central-West Region Development Program (POLOCENTRO) as a national policy. This program combined the construction of roads, storage facilities, local public services, and agricultural credit, in targeting areas of the region. As mentioned above, EMBRAPA established the Cerrado Agricultural Research Center (CPAC) a year before. 
On the basis of the successful PADAP experience, the Japan-Brazil Cooperation Program for Cerrados Development (PRODECER) was launched in 1979 to extend Cerrado agriculture to other areas of Minas Gerais. The pilot projects of the first phase of PRODECER fully demonstrated the feasibility and high potential of Cerrado agriculture. The second phase of PRODECER carried out full-fledged projects in Minas Gerais as well as in the states of Goiás and Mato Grosso do Sul. At the same time, PRODECER also started pilot projects in the states of Bahia and Mato Grosso. The third phase of PRODECER covered the states of Tocantins and Maranhão.

In this way, PRODECER was scaled up and outwards from the core regions to the frontier regions of the Cerrado. In this process, there has been continuous learning and the accumulation of knowledge and capabilities for both the researchers and farmers. How did these groundbreaking technologies developed by EMBRAPA spread? How did the pioneers of Cerrado agriculture improve their technological capabilities after they settled in the Cerrado, once believed to be sterile, and strove tirelessly to establish agricultural land? As noted by Alves (2012), who is known as the father of EMBRAPA, many of the farmers who migrated to the Cerrado from southern Brazil had experience in agricultural production and were proactive about adopting new technologies. Cooperatives such as Cotia contributed greatly to the process of technological dissemination.

The Brazilian Enterprise for Technical Assistance and Rural Extension (EMBRATER) was initially in charge of disseminating technologies developed mainly by EMBRAPA. EMBRATER was dissolved as a part of administrative reform and deregulation policies in 1992. A recent study by the Inter-American Development Bank (2010, 320) points out that, after the organization was liquidated, producers utilized technological innovations through cooperatives and other organizations. In PRODECER, the growth pole strategy was adopted at Cerrado frontiers. Cotia and other cooperatives provided detailed technological consultations for individual farmers, contributing greatly to raising their technological capabilities.

\subsubsection{Institutions that Facilitated Changes of the Endowment}

The single most important institution that enabled the amazing change in the Cerrado and the establishment of Cerrado agriculture is considered to be EMBRAPA. The research begun by EMBRAPA in 1973 progressed steadily, making it one of the largest agricultural research institutes in the southern hemisphere and one of the largest tropical agricultural research institutes in the world. As of 2010, there were over 8637 people working with the institute, 2116 of whom were researchers, 1622 holding doctorates. Only three researchers with doctorates were with the institute at its founding in 1973. Since then, EMBRAPA has dispatched three thousand people to study at higher educational institutions in Western countries, and it now has forty-three affiliated research centers. EMBRAPA is today highly appreciated overseas for its distinguished research. Analyzing the factors behind its success reveals some clues on how to develop institutions capable of research and development activities suited to a country's conditions, which at the same time generate technological innovations, cultivate human resources, and produce "miracles" similar to that in the Cerrado.

EMBRAPA set the development of Cerrado agriculture as its core mission, made important advances thereby establishing its eminent position, thus succeeding in steadily securing and increasing its research budget while maintaining political neutrality. Consequently, as additional research results were obtained and translated into practical results, its position became increasingly stronger. Alves' (2012) comments on the success of EMBRAPA can be summarized as follows: What solidified the position of EMBRAPA was the achievement of transforming the Cerrado into a modern agricultural region. EMBRAPA's 
contributions are at the core of Cerrado agriculture, and society recognized that its involvement is vitally important for the region's success.

In addition, Alves and other authors emphasize other factors that made the EMBRAPA model successful: close relations between researchers and farmers, meritocratic incentive system and structure, transparency, and so on.

\subsubsection{Summary of Agricultural Development Process}

Figure 3.2 roughly illustrates the development process of the Cerrado agriculture in Brazil. It shows how experiences from the pioneering efforts of PADAP were scaled up to the first phase of PRODECER in Minas Gerais (MG) state, which was successfully expanded to the full-fledged projects in other zones of MG and the neighboring Goias (GO) and Mato Grosso do Sul (MS) states, and ultimately extended to other states of Cerrado (Mato Grosso, MT; Bahia, BA; Tocantins, TO; and Maranhão, MA). In this process, technological development and dissemination by EMBRAPA, established in 1973 and continuously strengthened in the whole process, has been crucial. The POLOCENTRO program carried out since 1975 by the Government of Brazil contributed a lot to the Cerrado agriculture during its establishment period.

\subsubsection{Case 3.3: Bangladesh Garment Industry}

In 1981, ten years after Bangladesh achieved independence, raw jute and jute goods made up $68 \%$ of the country's total exports. By 2011, garments and textiles constituted $85 \%$ of total exports, of which $76 \%$ was comprised of garments. Business engaged in the clothing industry amounted to $50 \%$ of all manufacturing establishments in the country (UNCTAD 2012, 11). Today, the garment industry has five to six thousand factories with seven to eight million workers employed in assembly line clothing production. The wages of the workers in these industries are around $35 \%$ higher than the

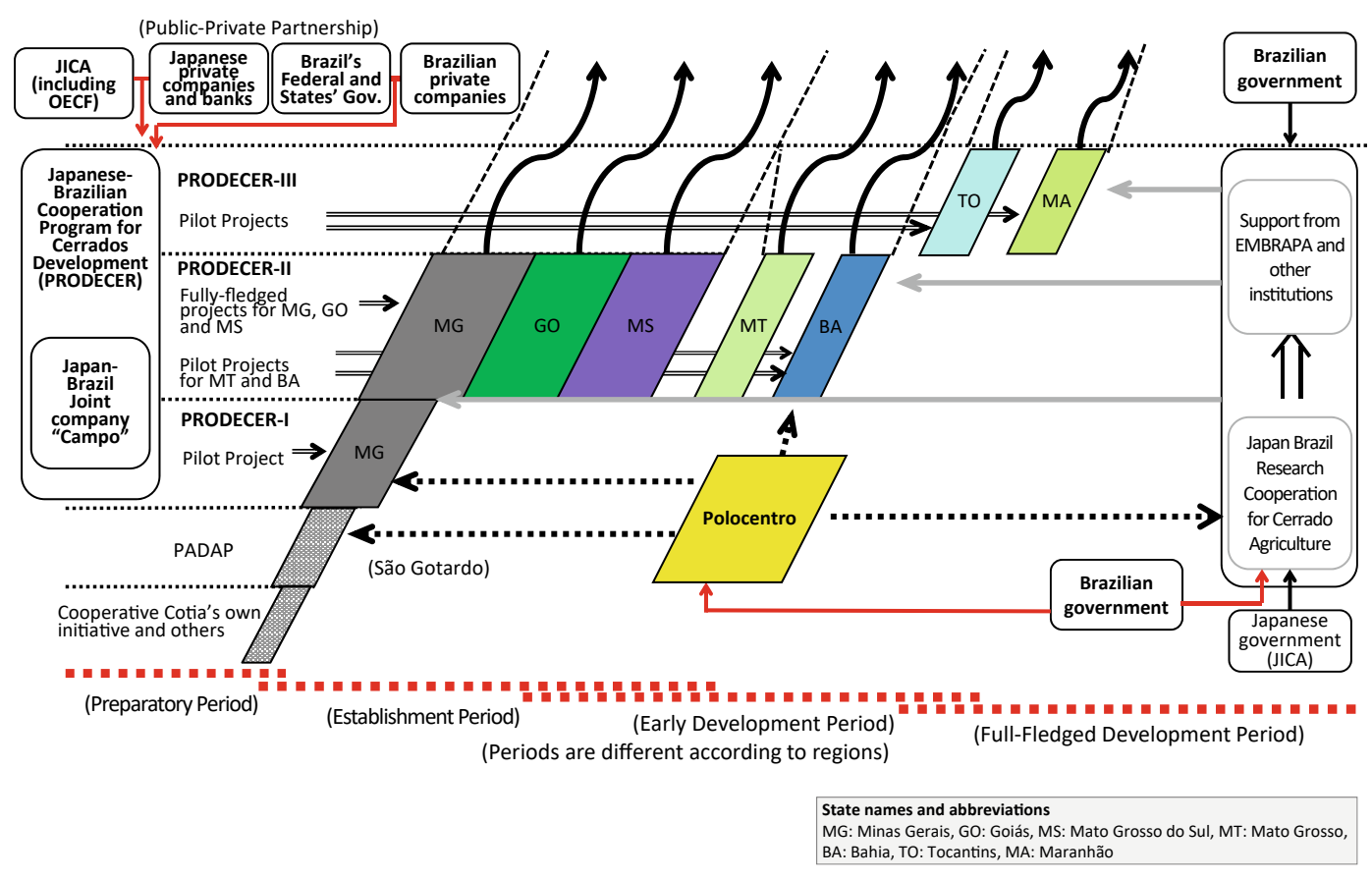

Fig. 3.2 Development of Cerrado Agriculture, Brazil. Source Prepared by the author, based on Hosono et al. (2016b) 
national average (11). Exports as a percentage of GDP tripled between 1990 and 2010, with much of the increase in the thriving ready-made garment industry with a largely female labor force. (World Bank 2012). This success story from Bangladesh is remarkable because, as a recent World Bank study highlighted, "the country was often held out in the development literature as a hopeless case" (197).

\subsubsection{Learning, Accumulation of Knowledge, and Capabilities}

Rhee (1990) undertook extensive research on how this country's garment industry started. In 1978 Daewoo of Korea proposed to the government of Bangladesh an ambitious joint venture involving the development and operation of tire, leather goods, cement, and garment factories. As it turned out, the Bangladesh government actually prioritised the garment industry first. Although the public and private sectors were particularly interested in the garment industry, Bangladesh was not exporting garments because of a total lack of domestic production technology and marketing knowhow, and had no apparent means of acquiring them from overseas (336). In this context, Noorul Quader, who had been introduced to the foreign business world as a senior official in the previous government, founded the Desh Garment Company and expressed the desire to collaborate with Daewoo in a new garment venture in the country (336). Quader and Daewoo signed an agreement to collaborate on technical training, purchase of machinery and fabric, plant start-ups, and marketing. Desh recruited 130 workers for training at Daewoo's Busan plant. Over seven months in 1979, "they received some of the most intensive on-the-job training in garment production ever seen in the history of developing countries" (337).

In addition to receiving in-depth, excellent skills training, Desh workers were also given a wide-ranging, high-quality education involving a look at the entire operations of a highly successful, multifaceted international company and the corporate culture that created and supported its superior performance, which Rhee emphasized as one of the most outstanding features of this training (338). The 115 Daewoo-trained workers who left Desh in the latter half of 1981 proved a very powerful medium for transferring knowhow throughout the whole garment sector and for significantly improving garment exports. By 1985, there were more than seven hundred garment export factories in Bangladesh, compared with only a few such factories in 1979. Rhee mentions that many new garment firms have been able to handle production and marketing without involving expatriates or foreign companies because they have been staffed by former Desh workers who had fully mastered production and marketing (342). However, he also recognizes the continuous need for many of these new factories to collaborate to some degree with foreigners in the areas of marketing and technology (342).

Another noteworthy feature of Daewoo's training was that there were fourteen women among the trainees. Rhee explains, "Muslim tradition had precluded females from working in factories in Bangladesh. However, Quader had been so impressed by the efficiency and sheer numbers of women at Daewoo and other garment factories in Korea that he persuaded the Bangladesh government to support female trainees" (337).

In terms of the learning and knowledge creation achieved through the Desh-Daewoo collaboration, Easterly $(2002,149)$ noted that "Creating knowledge does not necessarily mean inventing new technologies from scratch. Some aspects of garment manufacturing technology were probably several centuries old". Bangladesh has the legacy of Dhaka Muslin. "The relevant technological ideas might be out there floating in the ether, but only those who apply them can really learn them and teach them to others"(149). In this regard, Mostafa and Klepper $(2010,3)$ emphasize that tacit knowledge seeding was essential for the initial establishment and subsequent expansion of the Bangladesh garment industry. They contend that the key to the explosive growth of the industry was knowledgeable workers leaving Desh, and then other successful firms, to set up the production processes of later entrants. These workers organized 
an assembly line production process, trained workers, and supervised production, effectively diffusing vital tacit knowledge to new garment producers. Despite having limited literacy, Bangladesh had a sufficient number of educated entrepreneurs with some prior business experience who could gather the relevant resources and establish garment factories (29).

The process of learning and the accumulation of capabilities continued after this impressive transfer of technology from Korea. Mottaleb and Sonobe (2011, 4-5) conjectured that highly educated entrepreneurs were attracted to the garment industry by high profitability, which was boosted initially by the Desh-Daewoo infusion of Korean skills and knowhow. Their analysis indicated that the high-level education of manufacturers and enterprise performance were closely associated. This is because manufacturers have to continuously upgrade their skills and knowhow in order to survive the intense competition in the world garment market and because high levels of general human capital are necessary for the entrepreneur to manage an increasing number of managers and experts (20-21).

\subsubsection{Change of Endowments: Rural Development and Mobilization of Female Workers with Low Opportunity Cost}

The World Bank (2012, 197-199) classifies Bangladesh as an urbanizing country. Indeed the changes in rural society in this country have been profound and are closely related to the massive mobilization of female workers by the garment industry located mainly in two big cities: Dhaka and Chittagong. Generally speaking, urbanizing countries are endowed with abundant unskilled labor, and these countries' integration into the world economy can lead to the development of light manufacturing industries. In the case of Bangladesh, several factors interacted in order for this change to take place. Among the major factors that changed the rural society of Bangladesh was the modernization of agriculture based on technology that enabled farmers to shift from low-yield, single-crop, deep-water rice to the double cropping of short maturity, high-yield rice. Another factors were well-known rapid spread of microfinance and construction of rural infrastructure (197). More specifically, rural roads, irrigation, market facilities, and other rural infrastructure, microcredit, school education, and so forth provided by NGOs, central and local governments, and donors, all together enabled the remarkable agricultural and rural development of Bangladesh in the last three decades. In this process, the rural development programs of the government and donors were implemented effectively by the Local Government Engineering Department (LGED), which played a critical role in the provision of rural infrastructure ${ }^{11}$. Microcredit and related services were also effectively extended by NGOs, including BRAC and Grameen Bank.

This process enhanced the mobility and readiness of low-opportunity-cost labor in rural Bangladesh and gradually but steadily changed the endowments of the country. We should remember that a pessimistic appraisal was common regarding women's role in the labor market in Bangladesh, which caused pessimism about the country's growth, due in part to the fact that most East Asian countries had the advantage of a high female labor force participation rate at the start of the growth process. As Hossain et al. (2012, 29) emphasize, none of the predictions could anticipate that women would offer the secret ingredients of the success achieved in Bangladesh, from exports to schooling to microcredit use. The dramatic nature of the increase in female participation in the growth of ready-made garment (RMG) workers is a case in point.

The mobilization of this labor was triggered by the Desh-Daewoo garment project. As Rhee (1990) explains, "Development is a dynamic process in which self-generating mechanisms may emerge once action is initiated.... To start on the path of development in an outward-oriented direction, a first spark must be created" (45). That spark was the collaborative effort of a domestic catalyst (Desh) to mobilize the necessary local resources, and a foreign catalyst (Daewoo). It 
was a process of self-discovery of the changing comparative advantage of the country.

As such, the self-generating dynamic process of the garment industry was possible due to the changing comparative advantage with the mobility and readiness of low-opportunity-cost labor, particularly women, in rural Bangladesh. At the same time, the positive externalities the garment industry brought to the economy in terms of the empowerment of women, their increased schooling, use of microcredit, and so on, cannot be overemphasized.

Hossain et al. (2012) contend that in a predominantly agricultural economy with high population density and high population growth, the critical challenge is to reduce the burden of surplus labor in agriculture. They argue that "This challenge can be met through sustained sectoral and social policies and attendant institutional changes commensurate to each stage of development to support productivity/growthenhancing relocation of 'surplus' farm labor to non-farm and non-agricultural jobs" (5; italics in original).

\subsubsection{Change of Endowments: Connectivity and Logistics Upgrading by Infrastructure}

When Desh started its business in 1980, its factory was located in Chittagong, the country's main port. The first export processing zone (EPZ) was also constructed in 1983 in this port city. Exports from Dhaka, which does not have an efficient port facility nearby, had a serious bottleneck due to the lack of bridges spanning the rivers that cross Highway No. 1, which connects the capital city with Chittagong. As trucks had to use ferries, the transport between Dhaka and Chittagong was constrained by time and unpredictability. This handicap affected the competitiveness of the garment industry in Dhaka. It was overcome by the construction of Meghna Bridge in 1991 and Meghna-Gumti Bridge in 1995. The Dhaka EPZ was constructed in 1993.

The Jamuna multipurpose bridge, inaugurated in 1998 as the largest construction in Bangladesh history, has been a major channel for integrating the lagging western region of the country with the leading eastern region, enabling cheaper transportation of gas, electricity, and telecommunications, as well as enhancing the labor mobility of the western region (Hossain et al. 2012, 11).

\subsubsection{Institutions that Facilitated Garment Industry Development}

Initial conditions in Bangladesh, when the garment industry started with the Desh-Daewoo initiative, were affected by high levels of policy distortions and weak institutions. However, in spite of the rigidity of the government's response in terms of the adaptability of ideas coming from private entrepreneurs, which is very common in developing countries, in the case of Bangladesh, innovative ideas and strategies from entrepreneurs were well accommodated by government policymakers (Yunus and Yamagata 2012, 5). A back-to-back letter of credit (L/C) system $^{12}$ and special bonded warehouse facilities were two of the most important features and were formulated based on the prescription of the leading entrepreneurs.

The special bonded warehouses were critical to the initiation of garment export production. According to Rhee (1990), "It appears that Daewoo's intimate knowledge of the nuts and bolts of the successful bonded warehouse system in Korea, its ability to transmit that knowledge to Desh staff, and the advice that Desh's senior manager gave to administration officials on the new system were instrumental in the design and implementation of the special bonded warehouse system" (339). Although the government did not provide any import financing facility, it did allow the back-to-back L/C, which was a very effective instrument given the system of strict foreign exchange controls in the country at that time. Here again, Daewoo and Desh's influence on the public agencies was instrumental (340).

The consequent accelerated development of the garment industry was enabled by learning and the accumulation of the capabilities, as mentioned earlier. The government facilitated its development through infrastructure investment, 
construction of export processing zones, policies for the free importation of machines, bonded warehouses, and back-to-back L/C, followed by other general policies such as the new industrial policy (1982), revised industrial policy (1986), and credit facilities (1991). At the same time, the multifiber agreement (1985) and its quotas, as well as preferential access to the EU market, have been important factors.

On the other hand, a comprehensive set of labor market and social policies need to be introduced, as a recent study by the International Labor Organization (ILO) Research Department (2013) warns. A garment factory fire in November 2011, which killed 117 workers, and the April 2012 collapse of a building housing several factories on the outskirts of Dhaka, in which 1129 workers were tragically killed and another 2500 were injured, brought the issue of occupational safety of the Bangladesh garment industry to the world's attention.

\subsubsection{Summary of the Industrial Development Process}

Figure 3.3 roughly illustrates the development of the garment industry in Bangladesh. It shows the evolution of a number of garment factories from the 1980 s to today, together with the introduction of industrial policies and international frameworks related to the garment industry, such as the multifiber agreement and its expiration (see the right-hand side of the figure). The process has also been facilitated by infrastructure investments such as bridges and export processing zones (left-hand side of the figure). The figure also refers to incremental changes of endowments such as the accumulation of capabilities by small business owners, the mobility and readiness of female workers, changes in rural society, and so on.

A recent publication by Sawada et al. (2018) aimed to provide a comprehensive picture of the development of Bangladesh that is often termed a

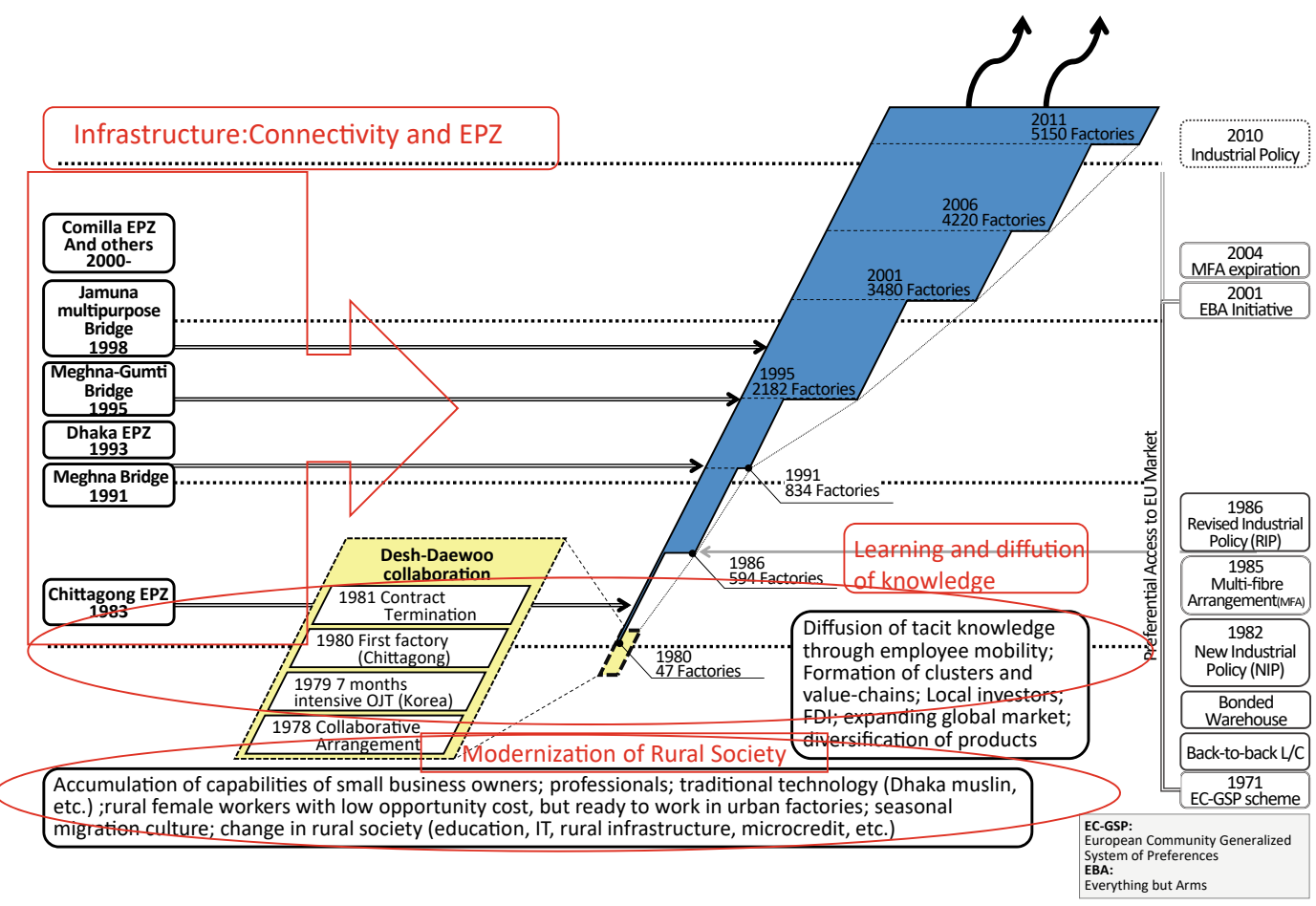

Fig. 3.3 Bangladesh Garment/Apparel Industry. Source Prepared by the author, based on BGMEA (2013), ILO (1993), Islam and Mukhtar (2011), Rhee (1990), Yunus and Yamagata (2012) 
Miracle" (xxvi, emphasis in original). The authors found that:

\begin{abstract}
Bangladesh's development transformation was fueled by three country-specific mechanisms: the penetration of microfinance institutions (MFIs) and other non-government organizations (NGOs) into rural communities that led to relaxed credit and other binding constraints on rural poor households; the spectacular development of the ready-made garment industry resulting in the rapid transformation of the economy from an agriculture-based to an industry-oriented one; and the significant investments in infrastructure, particularly in roads and bridges, which has helped to connect the formerly fragmented spatial economy.
\end{abstract}

Based on insights from this and other studies, it is clear that the garment industry has been the driving force that has led the transformation of Bangladesh's economy and industrial structure. It has been a key to its Miracle.

\subsubsection{Case 3.4: Chile's Salmon Industry $^{13}$}

Aquaculture is growing globally and makes up almost $50 \%$ of the global fish harvest in what is called the "blue revolution" (drawing a comparison with agriculture's green revolution) (OECD 2008, 85). One of the most impressive cases of the blue revolution is Chile's salmon farming and processing industry.

Salmon did not exist in Chile four decades ago. Now, Chile is one of the world's top salmon-exporting countries, producing approximately $40 \%$ of the world's farmed salmon, and is ranked on par with Norway. Chile is a resourcerich country highly dependent on copper exports, faced with the challenge of diversifying its exports. In 2011, exports of mineral ores and their refined products corresponded to more than $60 \%$ of total exports, $52 \%$ of which were copper ore and refined copper. The ensuing export revenue from rich resources led to a strong real exchange rate appreciation and deterioration in competitiveness in sectors exposed to international competition (World Bank 2012, 199). Salmon is the second-largest export sector of Chile after copper, and its export value amounted to $\$ 3517$ million in 2013 . The sector employs more than sixty thousand people in four southern regions of the country ${ }^{14}$.

\subsubsection{Change of Endowment by Technological Adaptation/Innovation}

Chile's comparative advantage in salmon sea farming was definitively affirmed when a subsidiary of the Chile Foundation, Salmones Antártica, demonstrated the commercial feasibility of salmon aquaculture at a scale of one thousand tons per year in 1988. The Chile Foundation (Fundación Chile in Spanish) is a public-private corporation that aims at developing technologies for establishing new industries, setting up businesses, and selling successful ones for profit. This unique organization, which has no equivalent elsewhere in Latin America, was created through compensation consultations undertaken by the Chilean government in the mid-1970s with an American multinational corporation that had been nationalized by the previous government.

In general, for a new industry to be established so that it grows in a self-sustaining manner, the industry must demonstrate its feasibility and international competitiveness as a sustainable profit-making business. This requires, as a precondition, technology development, which in turn calls for sizable investment. Many venture businesses invest in the development of such technologies and new products. Although technology development itself carries the risk of failure, the guarantee that the founder's profits will be secured under the protection of patent rights provides a substantial incentive for creating a new industry. This is not to say, however, that the founder's profits in a new industry are always protected by patents or other means, and there are in fact many cases to the contrary.

There are difficulties specific to developing countries that are trying to catch up with developed countries. For example, entrepreneurs that are seeking to develop a new industry with the help of technology transfer from other countries usually find it difficult to protect the technologies gained through such transfers, as they will not be 
protected by patents. As a result, as soon as a company succeeds in a technology transfer, others will soon follow in the successful company's footsteps. This will intensify competition. In this case, the profits the pioneer deserves may not be guaranteed. Or worse still, the investment may not be recouped. Therefore Rodrik (2007, 117) argues that the costs of "self-discovery" of pioneers should be subsidized.

This may be described as a case of market failure in that open access to the information in question discourages investment. Specifically, this is known as market failure associated with "information externalities." In the case of Chile in the 1970s and 1980s, the government did not take an interventionist policy of directly supporting the development of industries. However, it is clear that the Chilean salmon industry was not developed as a result of the private sector making voluntary investments from the outset. In this context, noting that the major export items for Chile include copper, grapes, fish, and lumber/wood, Rodrik stresses that the diversification of export products from copper had not been achieved in a laissez-faire market (109).

In the case of the Chilean salmon industry, market failure was averted by the Chile Foundation and Japan-Chile salmon project. The Chile Foundation, a newly created, semi-governmental foundation, made an investment large enough to support salmon production through sea farming on a major scale and successfully recouped this investment. The foundation thus demonstrated the commercial profitability of sea farming on that scale. In addition to proving the profitability of the venture, the Chile Foundation provided information on salmon farming as a public good for free or for a fee so as to allow many companies to invest in the salmon farming industry without having to make a sizable investment in research and development.

Two private companies had started salmon sea farming before the Chile Foundation started its salmon initiative. In 1978, Nichiro Fisheries of Japan, which had already accumulated salmon sea farming technologies in Japan, set up Nichiro Chile. In 1979, Nichiro launched salmon sea farming near the city of Puerto Montt, the first of its kind in the country. This was a groundbreaking event that surprised fisheries experts at home and abroad. Following Nichiro's groundbreaking success in salmon farming, the Chile Foundation acquired the facilities that Domsea Pesquera - a company under the umbrella of Campbell Soup of the United States-had owned in Chiloé Island and elsewhere. This represented the starting point for the Chile Foundation to enter the salmon industry in earnest.

Nichiro's success in pioneering mariculture and its commercialization in Chile had a great impact on the success of the semi-governmental Chile Foundation. According to Nichiro's corporate history, "The Chile Foundation of the Republic of Chile had been keeping an eye on our progress in coho salmon seafarming. Upon learning about our success, the foundation wasted no time in launching feasibility studies on sea farming" (Maruha-Nichiro Salmon Museum). Though it was a latecomer to the industry, following the trailblazing Nichiro and Mytilus (latter-day "Mares Australes"), the second entrant into the market, Chile Foundation's Salmones Antártica successfully put larger-scale salmon mariculture on track. What factors lay behind this success? In short, the Chile Foundation was a semi-governmental corporation capable of mobilizing ample risk capital. Originally designed to encourage venture businesses, the Chile Foundation was in a better position to promote salmon farming than private companies in general.

The Chile Foundation, following the successful achievement of the one-thousand-ton program, decided to sell the venture to a private company. This led to an international bidding contest in 1988, in which many companies participated. Nippon Suisan Kaisha (today Nissui), one of the major fisheries in Japan that operated in Chile at that time, won the bid. As a result, Salmones Antártica became wholly owned by Nippon Suisan Kaisha, which had been conducting salmon and trout businesses in the North Pacific Ocean since before World War II and had acquired advanced technical capabilities.

The Chile Foundation unexpectedly came up with the idea of offering corporate consulting 
services, instigated by the broadcasting in 1986 of a TV program featuring salmon farming, made in cooperation with Salmones Antártica. Many Chilean entrepreneurs who watched the program made inquiries to the TV station; some of them later ventured into the salmon industry. In the mid1980s, the Chile Foundation supported projects being undertaken by seven private companies.

\subsubsection{Learning and Accumulation of Capabilities and Knowledge}

In the case of the Chilean salmon industry, the natural conditions, capital, and labor were generally favorable. With technological adaptation and development, the value of these endowments changed, enabling Chile to attain a new comparative advantage. However, R\&D professionals and trained industrial personnel were still scarce. Introducing and developing technology with high-level professionals is not an easy task for the private sector. Industrial personnel cannot be trained overnight, and such training is expensive for the private sector. In the preparatory phase of the Chilean salmon industry, these circumstances made it difficult for private companies to develop technologies and train industrial personnel by themselves.

This gap was filled by the Japan-Chile Salmon Project, which was implemented for twenty years, beginning in 1969, by the Japan International Cooperation Agency (JICA) and its counterparts, the National Fishery Services (SERNAPESCA) and Fishery Promotion Institute (IFOP), under an agreement between the Japanese and Chilean governments. Because the Japan-Chile Salmon Project was under the auspices of these two government agencies, technologies developed and personnel trained by the project were "public goods" and were available to what was to later become the salmon industry in Chile. This allowed salmon firms to save on the cost of investment in industrial personnel training. The Chile Foundation also played a similar role.

Between 1969 and 1989, twenty-eight Chileans received training in Japan under the salmon project, which was implemented by JICA and its counterpart organizations in the Chilean government: firstly, SERNAPESCA, including its predecessor the Agriculture and Livestock Service (SAG), and secondly, IFOP. The training participants to be dispatched to Japan were selected from Chilean professionals who had been assigned to the project in order of priority based on consideration of their work assignments. What the Chilean participants learned in Japan, where the technology of seed production and fry farming was advanced, as well as in the joint project, later translated into their own specialties. This in turn proved to be of great help in establishing and developing the salmon farming industry in Chile.

The Chilean fishery journal AQUA (2007) attracted the attention of people involved in salmon farming in Chile when it issued a twentiethanniversary special issue in December of 2007. The article on the aquaculture pioneers in Chile carried pictures of familiar faces who had worked in the industry for more than two decades. In all, six out of the eleven pioneers in salmon farming in Chile had received training in Japan. Of the six, five played a central role in the Japan-Chile Salmon Project over a long period.

\subsubsection{Institutions that Facilitated the Development of the Chilean Salmon Industry}

As explained earlier, in order to establish the Chilean salmon industry, it was important to demonstrate that the salmon business was promising and commercially viable. This was accomplished through feasibility studies and investments in the salmon business by the Chile Foundation. In addition, the Chile Foundation's feasibility studies were partly supported by the Japan-Chile Salmon Project. Together with technology development, industrial personnel training was an important activity in this establishment phase.

It was not until the full-fledged development phase that salmon industry clusters increased their importance as an innovation system. It is worth noting here that the nascent form of this innovation system was already emerging in the establishment phase and that the Chile 
Foundation and the Japan-Chile Salmon Project contributed to the process. Although industrial clusters in a wider sense include research institutes and universities, Chilean universities did little in the role as members of such clusters at the beginning. The scale-up of salmon production resulted in the deepening of the division of labor, the expansion of the value chain, and the development of salmon industry clusters involving a wide range of components, including salmon farming companies and their affiliated firms, government agencies, universities, and research institutes. One of the organizations that played an important role in this context was the Chilean Association of Salmon and Trout Producers (APSTCH, today SalmónChile). The Chile Foundation again made a significant contribution here, supporting the establishment of APSTCH.

The Chilean government, through its specialized entities SERNAPESCA and IFOP, and the Japan-Chile Salmon Project also served as a catalyst and played a facilitating role by contributing to technological development in the area of national salmon egg production, fish diseases management, and fry farming. Furthermore, the Japan-Chile Salmon Project contributed a great deal to the establishment and enforcement of relevant laws and regulations. The Office of the Undersecretary of Fisheries of the Ministry of Economy, Development and Tourism, established in 1978, played a pivotal role in establishing relevant laws and regulations, while SERNAPESCA assumed the responsibility for their enforcement.

Each of these two organizations served as the counterpart organization of JICA. SERNAPESCA, the Chilean counterpart organization for the Japan-Chile Salmon Project until 1987, put many of the project's outcomes to good use in establishing laws and regulations concerning the aquaculture industry in Chile. For example, technical cooperation in the area of fishery disease control has resulted in the development of regulations on the prevention of infectious disease epidemics associated with salmon and trout farming. Likewise, a Chilean Ministry of Economy ordinance issued in 1985 has imposed control over imported salmon eggs. The ordinance has also provided for the disinfection of hatcheries, among other control measures. In addition, it has prompted veterinary checks on farmed salmon, making the ordinance the starting point for salmon infectious disease control in Chile.

\subsubsection{Summary of the Development Process of the Salmon Industry}

Figure 3.4 roughly illustrates the development of the salmon industry in Chile. It shows the evolution of salmon industry companies from the 1970s, together with the research and development activities of Chilean National Fishery Services (SERNAPESCA) and Fishery Promotion Institute (IFOP) carried out with Japanese cooperation. After Nichiro Chile launched salmon sea farming in 1979, the Chile Foundation, a newly created, semi-governmental foundation, made an investment large enough to support salmon production through sea farming on a major scale and successfully recouped this investment, demonstrating the commercial feasibility at a scale of one thousand tons per year in 1988.

\subsubsection{Case 3.5: Singapore}

Singapore, a country without natural resources and with a large number of unemployed people at the time of its independence, is today one of the world's most competitive countries. The experience of Singapore is particularly relevant as a small country that experienced highly successful industrial development and economic transformation. Its population was 2.6 million in 1985 and 5.7 million in 2019. A small country faces a different challenges than larger countries do and needs to adopt different strategies.

Singapore was one of the first Southeast Asian countries to promote export-led growth rather than import substitution-led growth. In the late 1970s, faced with rising competition from other exporters whose wage rates were lower, Singapore decided to transition from exports dependent on cheap labor into a knowledge economy based on skilled labor and higher value-added 


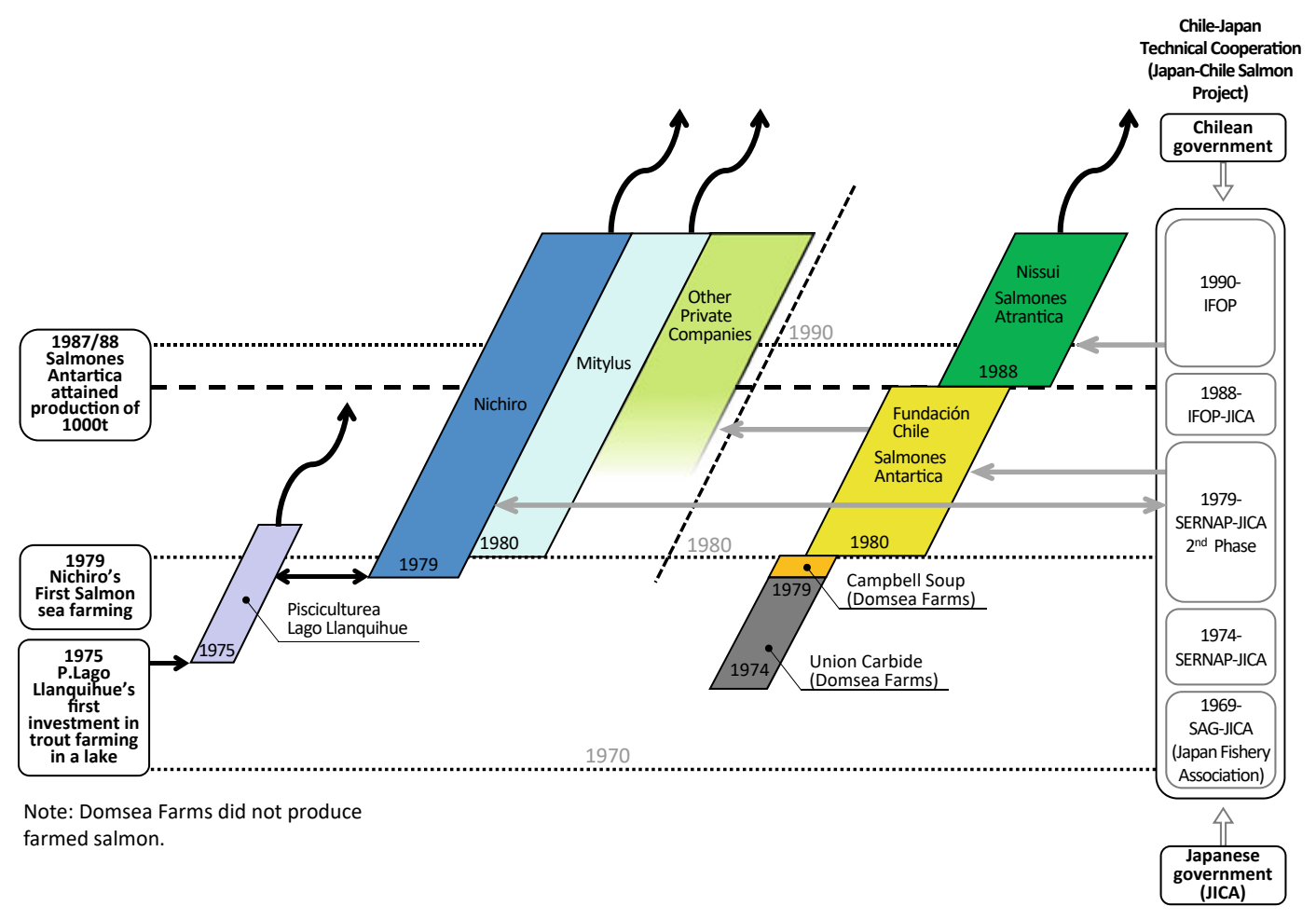

Fig. 3.4 Pioneer companies and institutions in the establishment and early development phases of Chilean salmon industry. Source Prepared by the author, based on Hosono (2015)

exports. During the last three decades, the country has continuously upgraded its industrial structure, overcoming the so-called middleincome trap. As Yusuf and Nabeshima (2012) note in their study on Singapore, Ireland, and Finland, by the 1980s it was becoming apparent that by betting on the technologically dynamic industrial subsectors-principally electronics, telecommunications, chemicals, and pharmaceuticals-small countries could improve their longer-term growth perspective.

In Singapore, rapid transformation demanded increasingly higher-level human resources and entrepreneurs. Foreign direct investment played an important role in transferring and disseminating cutting-edge technology, especially in the areas of electronics, the Internet, and biotech industries. In this case, transnational companies would not have been interested in investing in Singapore if the country had not had the human capital and knowledge base to absorb such technologies. This section provides insights into how human resource development and accumulation of capabilities was achieved. Following this the institutions that formulated the country's development strategy and facilitated the transformation will be discussed.

\subsubsection{Human Resource Development and Accumulation of Knowledge and Capabilities}

In the transformation process of Singapore, Yusuf and Nabeshima (2012, 34-36) emphasize the importance of general-purpose technologies (GPTs). They further argue that "The revolution caused by advances in semiconductors, electronics, and telecommunication technologies is widely associated with new products and the ways products are manufactured. Undoubtedly, these advances have contributed significantly to economic changes, but product innovation was 
powerfully reinforced by numerous collaborative innovations in other areas - for example, in services, institutions, organizations, and habits and lifestyles. GPTs have proven to be an extraordinarily potent transformative force because the learning economy generated a cross-disciplinary matrix of supporting and intersecting innovations that enormously magnified the influence of core technologies."

Yusuf and Nabeshima (2012, 44) go on to highlight that, in embracing technology as a driver of long-term growth, Singapore, Finland, and Ireland successfully engaged in building capabilities. This success comprises the core of the three countries' models and has resulted in the making of a networked learning and innovation system of the highest rank. Such capabilities might be emcompassed by the concept of "learning to learn," coined by Greenwald and Stiglitz (2012). In this same publication, Greenwald and Stiglitz stress that development strategies need to be focused on "learning to learn," especially in an era with fast-changing technologies in which specific knowledge learned at one moment risks rapid obsolescence.

So how did Singapore succeed in building such capabilities? A close look at Singapore's national initiative to increase productivity, strengthen quality, and later, support innovation will help us to understand Singapore's experience. According to Prime Minister Lee Kuan Yew, "The shift to a knowledge-intensive industrial structure with strong international competitiveness is only possible through the human-resource development of 2.6 million people, the only resource Singapore has" (Japan Productivity Organization 1990,1$)^{15}$. Lee was concerned with how to organize and motivate Singapore's labor force in such a way as to make the most of plant modernization and skills development (JICA/IDCJ/IDJ 2010, 30). In April 1981, the Singaporean Committee on Productivity was formed, comprising representatives of enterprises, workers' organizations, government officials, and academia. The committee reviewed the experiences of productivity movements in Japan, another country without natural resources but with abundant labor. It then presented a report to the president of the National Productivity Board (NPB) of Singapore, which had been designated as the main body for promoting productivity development in Singapore. In June 1983, the Singapore Productivity Development Project (SPDP) was launched with the support of the Japanese government.

Some fifteen thousand Singaporean engineers, managers, and other professionals participated in the project. Two hundred engineers, managers, and other professionals from Singapore took part in training courses in Japan, and more than two hundred Japanese experts were dispatched to Singapore. In addition, more than one hundred textbooks and other training materials were prepared specifically for the project. During the period of SPDP and beyond, labor productivity in manufacturing industries improved by an annual average rate of $5.7 \%$ (1981-1986), 3.0\% (1986-1991), and 4.8\% (1991-1996). ${ }^{16}$

In 1990, when SPDP ended, $90 \%$ of workers in the country were involved in productivity development activities, compared with 54\% in 1986. In 2001, $13 \%$ of the total labor force was participating in quality-control circles, in comparison with $0.4 \%$ in 1983 , when SPDP started. Quality control circles are considered the most effective vehicle for improving quality and productivity with the active participation of workers. Through this participatory approach, workers' ideas are incorporated into the production process, leading to innovative solutions to address ever-changing challenges. Hence, SPDP became one of the driving forces for productivity gains in Singapore.

NPB's activities gathered considerable momentum, progressing from the awareness stage (1982-1985), during which it created widespread awareness of productivity among companies and the workforce, to the action stage (1986-1988), when it translated awareness into specific programs to improve productivity in the workplace, and finally, the follow-up stage (1988 to the present), in which it encouraged ownership of the productivity movement (see Ohno and Kitaw 2011; Ohno 2013). The NPB merged with the Singapore Institute of Standards and Industrial Research in 1996 to create the Productivity 
and Standards Board (PSB), bringing together the soft skills and the technical aspects of productivity. The PSB was later strengthened and reorganized into the Standards, Productivity, and Innovation Board (SPRING) in 2002.

Progressively, the NPB, PSB, and now SPRING has become a global center of excellence in the fields of productivity, quality, standards, and innovation. Other key factors that bolstered this institution include the transition from a public-sector-led entity to a private sectorled entity, active advocacy and publicity, human resource development inside and outside the institution, and the establishment of a skills development fund by the government. Singapore's productivity initiative was strongly encouraged by the country's senior leaders, especially Prime Minister Lee. He understood the need for institution-building and the need to promote creativity and the capacity to innovate in order to sustain growth for Singaporeans.

It should be emphasized here that the previously mentioned process enhanced the capabilities of both individuals and organizations. Ohno $(2013,190)$ reiterates that a nationwide productivity drive requires a paradigm shift, a mindset change by which all people strive for and acquire the habit of improvement, and systems and practices that translate such attitudes into action. He further emphasizes that new ways of thinking, living, and working must be firmly built in the minds and actions of all leaders and actors. This highlights the importance of strong political commitment from the top and solid organizational support.

\subsubsection{Institutions that Enabled the Process of Transformation}

Singapore's Economic Development Board (EDB) was a single agency given the task of delivering the key elements of a growth strategy (Yusuf and Nabeshima 2012, 105). It was established in 1961 with the original goals and organizational structure spelled out in its first annual report: "The primary function of the
Board is to promote the establishment of new industries in Singapore and to accelerate the growth of existing ones" (cited by Schein 2001, 38). Schein, based on an extensive study of EDB, described the culture of EDB as "strategic pragmatism." He argued that Singapore displayed a remarkable adaptive and learning capability without sacrificing short-term problem solving (57-58).

Ohno $(2013,172-173)$ points out that EDB is a business-friendly, one-stop agency for domestic and foreign investors. In attracting FDI in priority sectors, EDB uses both broad-based approaches and targeted approaches. EDB also engages in individual negotiations with foreign companies to offer company-specific support and incentives in what is called the "Queen Bee" approach. Singapore held first position among more than 180 countries in the World Bank 'Doing Business Reports from 2007 to 2011.

Kuruvilla and Chua (2000, 40-41) argue that there are several major reasons behind Singapore's remarkable success in upgrading workforce skills. These include a general link between economic development needs and skill formation/development facilitated by an institutional structure that places the EDB at the center of the efforts with responsibility for both areas. There is also EDB's model of technological transfer that links FDI to skills development. And finally there is also joint governmentprivate sector operation for skill training and educational reform for long-term skills development.

In the areas of productivity, quality, standards, and innovation, NPB, PSB, and now SPRING have played crucial roles in mainstreaming crosscutting general-purpose technologies (GPTs) in Singapore's industrial development and economic transformation.

Furthermore, the provision of infrastructure for industrial development by Jurong Town Corporation (JTC), as the principal statutory board for industrial development, cannot be overemphasized. JTC is seen as a strategic developer of cutting-edge industrial spaces 
bringing forth new paradigms in industrial planning and urban design (Kaushik 2012, 13). It now aims at strategic clustering and innovation, providing new estates, cluster hubs, paradigms, land creation, and eco-sustainability.

\subsubsection{Summary of the Process of Development of Institutions \\ for Accumulation of Knowledge and Capabilities}

Figure 3.5 roughly illustrates the growth of institutions in Singapore responsible for economic development, productivity, standards and innovation, and infrastructure provision. It focuses on the evolution over fifty years of such institutions as the Productivity and Standards Board (PSB) and the Standard, Productivity, and Innovation Board (SPRING), with both considered essential for productivity development, accreditation of products, standardization, and scientific research and development in Singapore.

\subsection{Concluding Remarks: Findings from the Case Studies}

The five cases presented here show how distinctive critical factors identified by several recent studies interact in practice. Learning and accumulation of knowledge and capabilities are essential, and occur in a gradual, incremental, and generally path-dependent process. However, the process is critical for changing the endowments to attain dynamic comparative advantage. Our case studies also bring out how the government or public institutions can facilitate the process. In Thailand, Bangladesh, and Singapore, the constant improvement of the capabilities of those involved in the new industries was crucial.

Change of endowments is also attained by infrastructure construction and technological innovation. Both factors can often trigger or accelerate industrial development and transformation. The Eastern Seaboard was crucial for the expansion of the automobile industry in Thailand, which eventually enabled the country to be labeled the "Detroit of Asia." In Bangladesh,

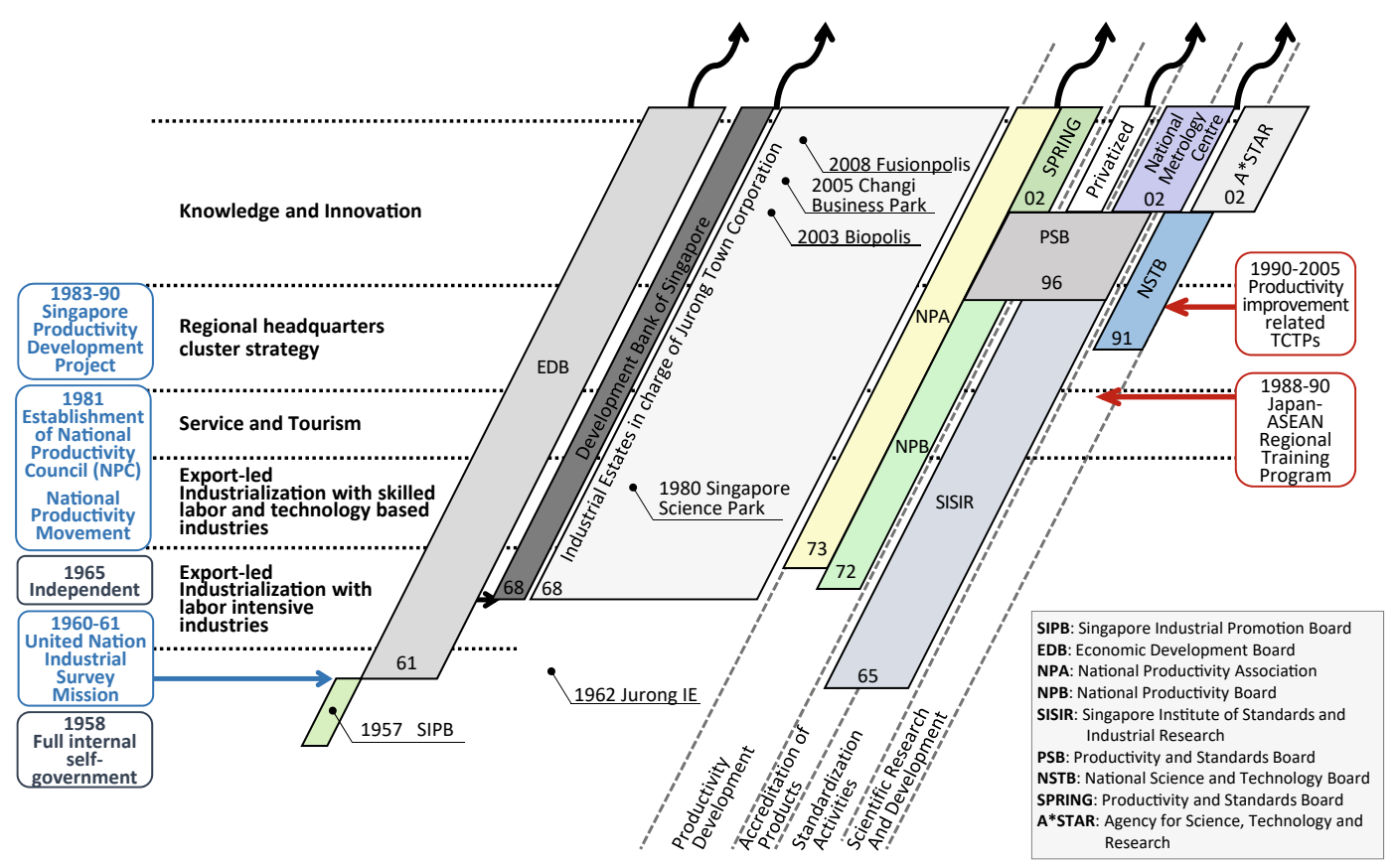

Fig. 3.5 Development of high value-added goods and service sector in Singapore. Source Prepared by the author 
construction of more efficient transport and logistics infrastructure facilitated and accelerated the process of transformation. In Brazil, technological breakthroughs changed the endowments and comparative advantage of the country and, together with institutional innovations, triggered the transformation of the Cerrado from barren land into one of the most productive agricultural regions in the world. In Chile, technological adaptation and development changed the endowments. But in all of these cases, industrial development and economic transformation could not have happened without constant development of capabilities and knowledge through learning. In Singapore, "learning to learn" was a key factor in the country's rapid and profound transformation.

Thus, in all outstanding cases studied, economic transformation was achieved with changes in endowment and comparative advantage. The endowment changes were enabled both by the long-term process of accumulation of knowledge and capabilities and by investment in infrastructure and in technological innovation. In particular, the technology and knowledge necessary for new economic activities, especially in agriculture and aquaculture, are normally considered public goods. These public goods were provided by public institutions or via public-private collaboration.

In all five cases, effective institutions accomplished the role of facilitator or catalyzer of transformation. First of all, many of the institutions were created for specific purposes and had long-term visions and missions. Second, most such institutions regarded public-private interaction, consultation, and coordination to be of the highest priority, as was seen in the cases of Thai automobile industry policymakers, the Brazilian Agricultural Research Corporation, Bangladesh garment industry policy-makers, the Chile Foundation, and Singapore's Economic Development Board and Standard, Productivity, and Innovation Board. Third, most of these institutions adapted flexibly to changes in the global market and phases of industrial development.

These findings generally confirm the conclusion of JICA/JBIC (2008) regarding drivers of economic growth found in the Asian experience, drawing from many other remarkable cases of changing endowments and transformation in the region. Particularly noteworthy are mid- to longterm visions for development and associated strategies; flexibility in responding to a changing environment; the government's close ties with the private sector; and harnessing the private sector's capacity to the maximum.

\subsection{Further Discussion (3.1)}

\subsubsection{Catalytic Role of International Cooperation}

The insights derived from the analysis of this chapter could provide policy implications regarding the catalytic role of international cooperation for industrial development and transformation. The UN High-Level Panel of Eminent Persons on the Post-2015 Development Agenda (hereafter UN HLP) called for a quantum leap forward in economic opportunities and a profound economic transformation to end extreme poverty and improve livelihoods (UN HLP on the Post-2015 Development Agenda $2013,8)$. The report further states that there must be a commitment to rapid, equitable growth-not growth at any cost or just short-term spurts in growth-but sustained, long-term, inclusive growth that can overcome the challenges of unemployment. In achieving this, the donor community now faces a challenge: "how to respond to the challenges of the UN High-level Panel, which has called for a 'quantum leap' to 'improve livelihoods', and become more ambitious in using aid for structural transformationusing the insights of the new industrial policy to use aid in a more concerted strategy for employment generation" (UNU-WIDER 2014, xi).

While the literature on aid growth relations is abundant, studies on the effectiveness of aid on economic transformation for jobs and inclusive growth are scarce. Analysis of aid-employment relations is not identical with aid-growth relations because, as we can observe in some subSaharan countries, for example, growth is not necessarily accompanied by an increase in 
employment nor by economic transformation. For both the aid-growth nexus, especially from a long-term perspective, and the aid-employment nexus, it is structural transformation that really matters. Therefore, the UN HLP on the post2015 Development Agenda called for a transformation of economies for jobs and inclusive growth.

\subsubsection{Aid and Transformation Focusing on Inclusive Growth}

This chapter is written from this "economic transformation perspective." In order to discuss the aid-transformation-employment nexus, I consider the following hypotheses critical: (1) the effect of aid on employment needs to be assessed from an economic transformation point of view; (2) aid plays a catalytic, not a leading, role in development, especially through economic transformation; and (3) the "economic transformation for jobs and inclusive growth" agenda differs between countries due to the diverse challenges of transformation that are related to the phases of development, endowments, and many other factors, and therefore there is no "one-size-fits-all" strategy.

Because of the first hypothesis, an appropriate analysis of the aid-transformation-employment nexus could be the "meso" or "sector" level, focusing on the creation of new industries and diversification of existing industries, as well as the deepening of value chains consisting of related industries. The aid-growth issue has been addressed through an aggregate macroeconomic approach (UNU-WIDER 2014, x). As the UNUWIDER Position Paper on Aid, Growth and Employment emphasizes, "aggregate aid-growth research typically does not generate policy recommendations beyond suggestions that either provide broad empirical evidence as to whether the theoretical rationales for aid stand up in practice or not ... [I]t does not in and by itself provide detailed insights into what to do, what not to do, and what to do better in aid practice" (UNU-WIDER 2014, 5). The findings in this chapter support the view of UNU-WIDER, in that "One must look beyond standard aggregate macro-economic research, for example along the lines of Arndt et al. (2013), or by drawing on a wider range of more qualitative evidence related to the provision of aid" (5).

The second hypothesis refers to the catalyst role of aid in at least two aspects, drawing on Kharas et al. (2011). Firstly, developing countries are responsible for their own development and aid can only play a catalytic role. Development will not happen because of aid, but aid can make a difference. Secondly, aid is but one of many instruments of development and the catalytic impact of aid is often seen when other forces, like trade and private investment, are unleashed because of better economic policies and institutions supported by aid programs (2).

The third hypothesis refers to the different economic transformation agendas between countries due to the distinctive "transformation for jobs and inclusive growth" challenges they face. The transformation agendas of most agrarian countries are related to improvement of the productivity of agriculture and diversification of the industrial structure into higher value-added sectors like agro-industry and other light manufacturing, thereby overcoming the low-income equilibrium $^{17}$. Many countries of East Asia have to address the middle-income trap through transformation. Ways of responding to challenges of transformation for jobs and inclusive growth could differ due to a range of specific characteristics inherent in each country, such as natural resource endowments, with the corresponding possibility of Dutch disease and resource curse, demographic transition accompanied by the possibility of a demographic bonus, landlockedness, connectivity to large external markets, and so on.

Economic transformation, or structural transformation, is widely understood as the change of an economic structure from low- to highproductivity sectors. It is achieved by creating new industries with higher productivity, diversifying industries, and extending and deepening value chains. Change of endowments and other factors could trigger economic transformation 
and could provide drivers (driving forces) to maintain the momentum of transformation. Therefore, change of endowments through investment in soft and hard infrastructure, technological innovation, institution-building, learning and accumulation of knowledge and capabilities, and so on is essential for economic transformation (Chap. 2). In short, aid could be catalytic in changing endowments, as well as triggering the transformation process and maintaining its momentum.

\subsubsection{Opportunities and Capacity Nexus for Inclusive Growth}

As mentioned above, the UN HLP on the Post2015 Development Agenda $(2013,8)$ called for a transformation of economies for jobs and inclusive growth. This implies that economic transformation should be intrinsically related to jobs and inclusive growth. The report highlights the following first priority: "[to] create opportunities for good and decent jobs and secure livelihoods, so as to make growth inclusive and ensure that it reduces poverty and inequality." It also emphasizes the necessity of education, training, and skills for people to respond to the demands by businesses for more workers and to be successful in the job market (8-9). Thus, the UN-HLP report highlights the importance of opportunities and capacity nexus for jobs and inclusive growth.

Among literature on inclusive growth, the Framework of Inclusive Growth Indicators (FIGI) published by the Asian Development Bank (ADB 2013) presents a similar view. It asserts that the outcomes of inclusive growth are achieved through three policy pillars: the sustained economic growth and development of productive jobs and economic opportunities, social inclusion to ensure equal access to economic opportunities by expanding human capacities, and, finally, social safety nets to protect the chronically poor and address the risks and vulnerabilities of the population. FIGI is illustrated in Fig. 3.6, in which related factors not included in FIGI, as well as the role of ODA, are added to FIGI to adapt it to the purpose of this study.

The first pillar of FIGI is mainly attained by creation of new industries, diversification and upgrading of existing industries, and deepening value chains consisting of related industries. This process will generate employment opportunities that can be responded to by workers who have accumulated capabilities, through actions related to the second pillar. Typically, in manufacturing industries, micro-, small-, medium-, and largescale enterprises play an essential role in this process by recruiting and training workers. However, in other industries - typically in agriculture and fishery-but also often in services and even in manufacturing, individuals or families have to accumulate capabilities themselves because, in these sectors, they are the principal actors of productive units.

FIGI's second pillar, "social inclusion to ensure equal access to economic opportunity," includes the directive "access and inputs to education and health." This is a fundamental component of the pillar, because basic education is essential for human capital to enhance its capacity. However, in order for workers to respond to changing demand in the process of industrial transformation, advanced capacity development is required. As Cimoli et al. (2009, 2) argue: “A 'great transformation' entails a major process of accumulation of knowledge and capabilities ... Certainly, part of such capabilities builds on education and formally acquired skills. However, at least equally importantly, capabilities have to do with the problem-solving knowledge embodied in organizations-concerning, for example, production technologies, marketing, labor relations, as well as "dynamic capabilities' of search and learning." This view is related to the complementarity between learning at school (formal education) and learning at work to strengthen the capacity of learning to learn (Chap. 2).

The first two policy pillars of FIGI-the development of productive jobs and economic opportunities and social inclusion to ensure equal 


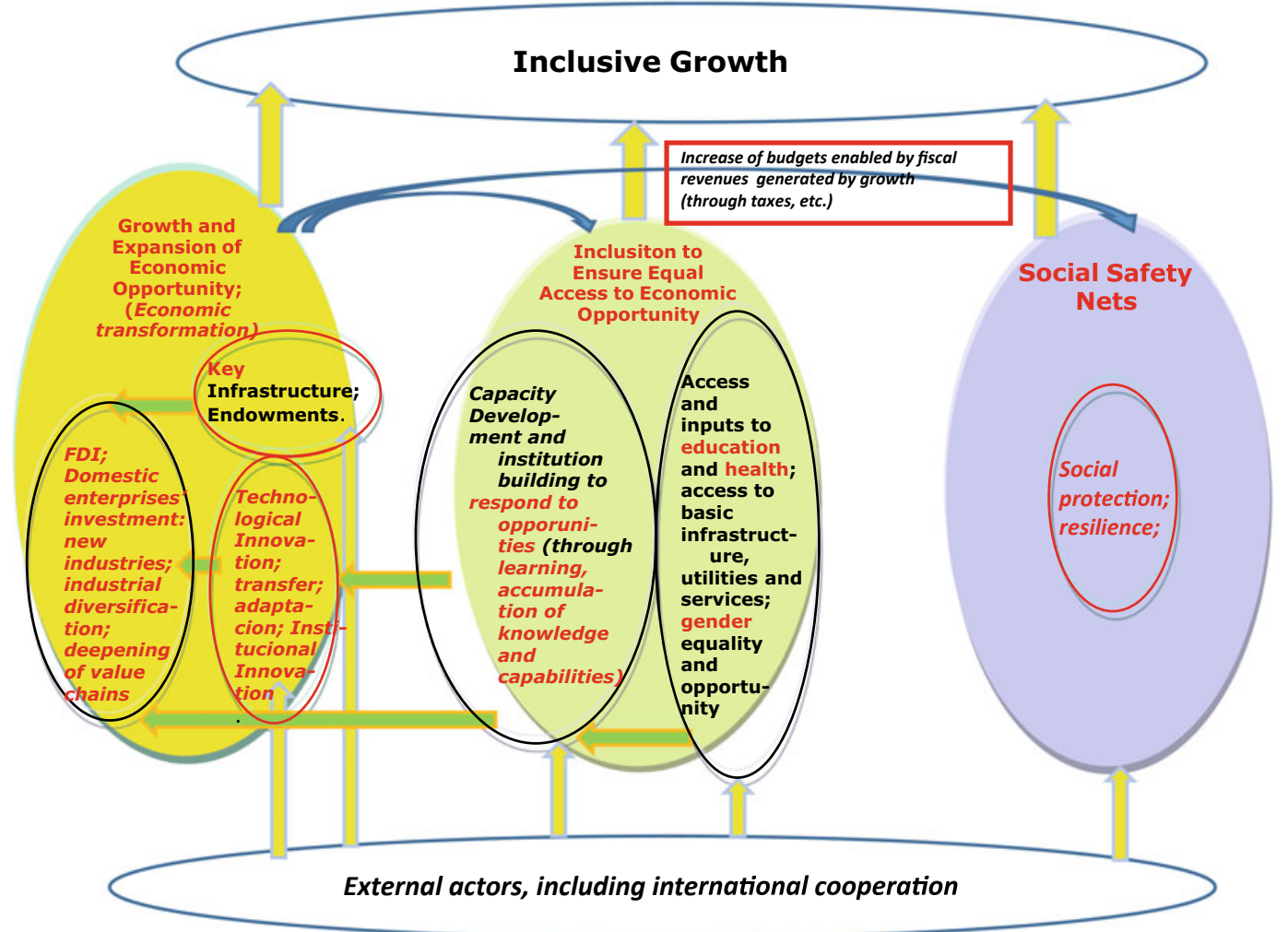

Fig. 3.6 Relationship between transformation and inclusive growth. Note This figure roughly illustrates the relationship between the main components of "inclusive

access to economic opportunities by expanding human capacities - are intrinsically related. Furthermore, FIGI, as well as the UN HLP on the Post-2015 Development Agenda, emphasize that the two pillars are mutually reinforcing, enabling the virtuous circle of these two pillars. Aid can play a catalytic role in economic transformation as mentioned above and, in particular, for economic transformation for jobs and inclusive growth. For example, it can do this through support for efforts to expand human capacities, which enables people to respond effectively to economic opportunities. It can also support industrial development, which increases employment opportunities. growth." Words in italic are added by the author. Source Author. Based on discussion of Hosono (2015) and ADB (2013: p. 4)

\subsubsection{Japan's View and Experiences}

This view coincides with Japan's view on ODA's role in development. The following statement of Japan's ODA White Paper (MOFA 2005, Part I), for example, explains concisely the view that: "Achieving economic growth requires improving the investment environment, which involves policy and institution building, human resources development, strengthening basic infrastructure, attracting foreign direct investment, and expanding trade. Japan has long insisted that economic growth through infrastructure development, etc., is crucial to poverty reduction, and has incorporated this viewpoint in its ODA policies." 
The importance of this viewpoint has been increasingly recognized by the donor community. For example, DAC Peer Review on Japan (OECD-DAC 2004) stated that "OECD considers FDI a major catalyst to development and suggests that developed countries can contribute to the promotion of these benefits by using ODA to leverage investments" (36). This peer review highlighted "Japan's comparative advantage in [the] infrastructure-FDI model" (32).

Japan's aforementioned viewpoint dates back to the mid-1980s when the so-called "trinity development cooperation" concept, meaning comprehensive economic cooperation packages with the trinity of aid, direct investment, and importation (from developing countries), was launched. It was formally announced in January 1987 by the Minister of International Trade and Industry of Japan under the title of "New AID Plan (New Asian Industries Development Plan)" (Shimomura 2013, 156). This concept was announced against the backdrop of the ASEAN countries' strong desire for economic transformation. As Shimomura put it, "they were desperately attempting to transform their primary goods-based export structure to one oriented towards labor-intensive light manufacturing goods, and further to technology-intensive manufacturing" (156).

After 20 years of implementation, Japan International Cooperation Agency's (JICA) Annual Evaluation Report $(2006,85)$ stated that the strategy utilizing trinity of aid, trade, and investment ultimately contributed toward the economic growth of developing countries. The report also explained how this strategy was carried out in practice.

In the case of Thailand's automobile industry, Japan's ODA provided support for infrastructure and human capital development, among other things, which substantially changed the endowments of Thailand and facilitated its economic transformation. The cooperation for the construction of infrastructure in the Eastern Seaboard could be considered a concrete example of the catalytic role of ODA leveraging investment for economic transformation toward higher value-added and more competitive activities.
Increasing numbers of skilled workers in this process responded to employment opportunities created by the development of car assembly industries and supporting industries that provide parts, components, and services. Indeed, transformation with jobs and inclusive growth took place in Thailand. JICA has dispatched experts to Thailand to provide technical and financial aid to small and medium enterprises (SME) since the early 1980 s. Since the mid-1990s, several projects for the promotion of SME/"supporting industry" have been conducted by JICA (see Fig. 3.1).

Here, the catalytic role of aid, discussed above, is clear. Through its contribution to change endowments, ODA catalyzed the process in which investment, both domestic and FDI from countries, including Japan, and trade were dramatically increased, enabling the development of a competitive automobile industry. Regarding this catalytic role of Japan's ODA, the DAC Peer Review on Japan (OECD-DAC 2004) elaborated "Japan's comparative advantage in infrastructure-FDI model," referring to the case of Asian countries' development as follows: "Japan has promoted FDI in the Asian region, developing its own model for enhancing economic growth by linking trade and investment policies with development co-operation" (36).

Nevertheless, the "infrastructure-FDI model" constitutes only a part of Japan's approach, which is much wider and includes other crucial components such as human resource development, thereby enabling workers to respond effectively to employment opportunities, and institution building, which is essential for economic transformation. Together with the general vision of Japan on aid (as cited above), Japan's ODA White Paper (MOFA 2005, Part I) stated the following, referring to the East Asian experience: "Direct investment from Japan's private sector and the resulting increase in exports and formation of markets, coupled with human resources development through ODA, spurred the East Asian economy to high growth. This expansion of private sector economic activity contributed to the improvement of the income of the poor through increased employment. On the 
basis of tax income from companies and citizens, the countries of East Asia expanded the delivery of public services, such as health care and education, leading to poverty reduction through human resources development."

As regards the agricultural development of the Cerrado in Brazil, the Inter-American Development Bank (IDB 2013, 41) highlighted the features of Japan's ODA in a similar manner as the DAC Peer Review (OECD-DAC 2004), cited above: "JICA has been a leader in providing aid for trade (AfT), which aims to develop countries' capabilities to integrate in the global economy through the development and enhancement of physical infrastructure, building private sector capacity, and supporting enabling policies and institutions .... Japanese cooperation has in fact played a central role in launching some of the region's most successful export sectors. Japanese technical assistance was critical in transforming Brazil's Cerrado region into the country's agricultural heartland" (IDB, 25-6).
Japan's view on quality of growth and poverty reduction through such growth as well as the catalytic role of cooperation is explained concisely in the Development Cooperation Charter of Japan (Cabinet Office, Japan 2015). Figure 3.7 roughly illustrates basic aspects of this Charter's view related to quality of growth and industrial development (for details, see the extracts below from the Charter related to these two points, as well as the catalytic role of aid/international cooperation).

\section{Summing Up}

In the five cases analyzed in this chapter, aid played a catalytic role in the process of transformation for inclusive growth, through support for investment in infrastructure and technological innovations, human resources and capacity development, as well as institution building. Although the aid was but one of many instruments of development, the catalytic impact of aid was seen because other forces like trade and private investment were unleashed, as the

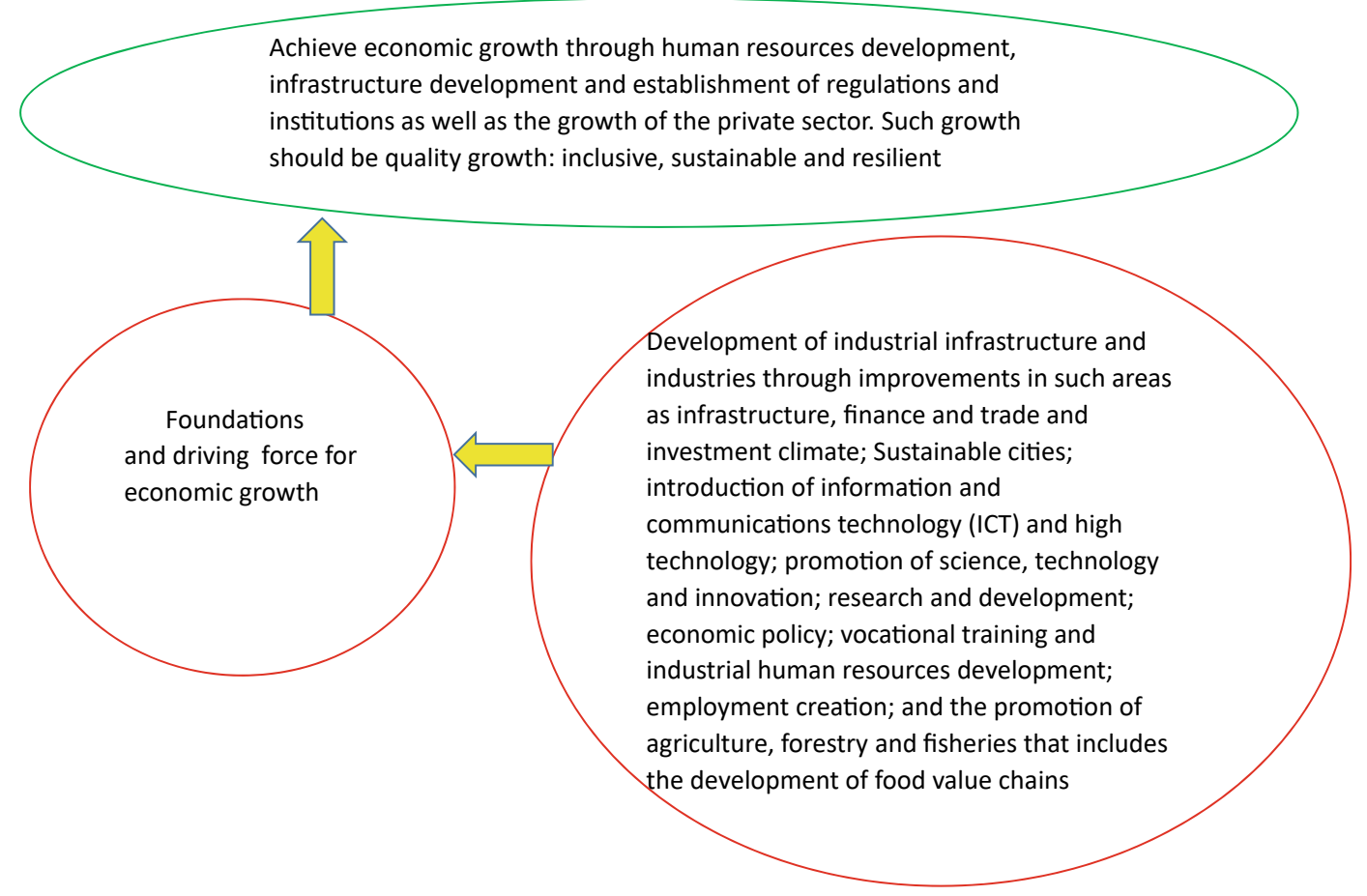

Fig. 3.7 International cooperation for the foundations and the driving force for economic growth. Source Author, based on Development Cooperation Charter of Japan 
process was underpinned by infrastructure, human resource development, appropriate policies and institutions, and so on, supported by aid programs.

[Extract from the Development Cooperation Charter of Japan related to "Quality of growth and poverty eradication through such growth"] (Cabinet Office, Japan 2015, 5-6).

The world's poor population is still large in number, and reducing poverty, especially eradicating absolute poverty, is the most fundamental development challenge. Especially as regards fragile states that have not been able to grasp the opportunities for development for different reasons and as regards people in vulnerable situations, it is important to provide both assistance from a humanitarian point of view and assistance designed to set the development process in motion and overcome vulnerability.

At the same time, in order to resolve the poverty issue in a sustainable manner, it is essential to achieve economic growth through human resources development, infrastructure development and establishment of regulations and institutions as well as the growth of the private sector enabled by the aforementioned actions, which are aimed at self-reliant development of developing countries. However, such growth should not be merely quantitative in nature, given that some of the countries that have achieved a measure of economic growth face challenges such as widening disparities, sustainability issues, inadequate social development, and political and economic instability. Rather, it should be "quality growth". Such growth is inclusive in that the fruits of growth are shared within society as a whole, leaving no one behind. It is sustainable over generations in terms of consideration to, among other aspects, harmony with the environment, sustained socioeconomic growth, and addressing global warming. And it is resilient, able to withstand and recover from economic crises, natural disasters and other shocks. These are some of the challenges Japan has tackled in its postwar history. Japan will take advantage of its own experience, expertise and technology as well as lessons learned in order to provide assistance to realize "quality growth" and poverty eradication through such growth.

From this perspective, Japan will provide assistance necessary to secure the foundations and the driving force for economic growth. Its scope includes: the development of industrial infrastructure and industries through improvements in such areas as infrastructure, finance and trade and investment climate; sustainable cities; introduction of information and communications technology (ICT) and high technology; promotion of science, technology and innovation; research and development; economic policy; vocational training and industrial human resources development; employment creation; and the promotion of agriculture, forestry and fisheries that includes the development of food value chains. At the same time, Japan will provide assistance necessary to promote people-centered development that supports basic human life, taking full account of the importance of human and social development. It encompasses health care, safe water and sanitation, food and nutrition, quality education for all, disparity reduction, empowerment of women, culture and sports that brings about spiritual affluence.

[Extract from the Development Cooperation Charter of Japan related to catalytic role of cooperation] (Cabinet Office, Japan 2015, 4-5).

In its development cooperation, Japan has maintained the spirit of jointly creating things that suit partner countries while respecting ownership, intentions and intrinsic characteristics of the country concerned, based on a field-oriented approach through dialogue and collaboration. It has also maintained the approach of building reciprocal relationships with developing countries in which both sides learn from each other and grow and develop together. These are some of the good traditions of Japan's cooperation which have supported self-help efforts of developing countries and aimed at future self-reliant development. On the basis of these traditions, Japan will continue to provide cooperation aimed at developing countries' self-reliant development by emphasizing their own initiatives and self-help efforts, as well as further deepening dialogue and collaboration with them while taking advantage of Japan's experience and expertise. In these processes, Japan will attach importance to building the foundations of self-help efforts and self-reliant development such as human resources, socio-economic infrastructure, regulations and institutions. It will also go beyond waiting for requests from partner countries by focusing on dialogue and collaboration with diverse actors not limited to governments and regional agencies of these countries, including proactively presenting proposals while giving full consideration to policies, programs and institutions related to development in the country concerned. In the present international community, various actors including private companies, local governments and non-governmental organizations (NGOs) play an increasingly important role in addressing development challenges and supporting sustained growth of developing countries. It is therefore important to mobilize a wider range of resources that are not limited to ODA. In this context, ODA, as the core of various activities that contribute to development, will serve as a catalyst 
for mobilizing a wide range of resources in cooperation with various funds and actors and, by extension, as an engine for various activities aimed at securing peace, stability and prosperity of the international community.

\section{Notes}

The author would like to express his gratitude to Yasuo Fujita, Go Shimada, and Ayako Otaguchi of JICA Ogata Sadako Research Institute for Peace and Development for their valuable comments. Errors and omissions are the responsibility of the author.

1. Greenwald and Stiglitz (2012) use a similar definition: "Industrial policies are what we call those policies that help shape the sectoral composition of an economy. The term is used more broadly than just those policies that encourage the industrial sector. A policy which encourages agro-business, or even agriculture, is referred to as an industrial policy" (3). For further discussion on "industrial policy," see Hosono (2022).

2. This typological approach is inspired by World Development Report 2013 (World Bank 2012, 18-19).

3. It goes without saying that the automobile is a complex product consisting of a large number of parts and components that involve different production processes and factor proportions. Many of these parts and components are manufactured by independent suppliers in other industries such as textiles, glass, plastic, electronics, rubber products, and steel and other metals (Athukorala and Kohpaiboon 2011, 1).

4. Regarding this new policy, see Natsuda and Thoburn $(2011,13)$.

5. Starting in 1978, the LCR for passenger cars was increased from 25 to $35 \%$ in the first two years and was then raised by $5 \%$ every year until 1983, eventually reaching $50 \%$, and for commercial vehicles from 20 to $45 \%$. The new policy also required assemblers to localize the production of specific parts by introducing a "mandatory deletion" scheme targeting specific parts such as brake drums and exhaust systems.
In 1994, the LCR was further raised to $60 \%$ for pickup trucks with gasoline engines and $72 \%$ for those with diesel engines. In 1996, the government announced the abolition of the LCR by 1998, prior to the WTO target date, although the period was eventually extended to 2000 (Natsuda and Thoburn 2011, 15).

6. Translation is by the author.

7. Cited in Techakanont $(2008,9)$.

8. This summary is based on JICA/JBIC (2008, 50).

9. Another study reached a similar conclusion: "It was the cumulative synergetic effect of a number of factors that had contributed to pushing the Eastern Seaboard Development Program forward. These included: Effective leadership to ensure the public's interest, competency of technocrats, powerful central economic agencies, special institutional settings, functioning coordination mechanisms, and external global factors" (Ohno and Shimamura 2007, 131; Shimomura 2017).

10. This case study is based on Hosono et al. (2016b, 2019).

11. The role of LGED in the rural development cannot be overemphasized. LGED is one of the largest public sector organizations in Bangladesh, with a staff exceeding ten thousand and a development budget accounting for 14\% (fiscal year 2009-2010) of the total development budget of the government. For details of LGED, see Fujita (2011).

12. For details of this system, see Easterly (2002, 149).

13. This case study is based on Hosono et al. (2016a).

14. See the SalmonChile (The Salmon Industry Association of Chile) website (www. salmonchile.cl). This figure does not include people employed by upper-stream and downstream industries of salmon farming and processing value chain.

15. Remarks made by the prime minister when he visited Kohei Goshi, honorary president of Japan Productivity Center in June 1981. 
16. The figures and those of the following paragraph are from JICA/IDCJ/IDJ (2010, 16 and 22).

17. Chapter 5 of this volume discusses strategies for inclusive growth in agrarian countries where extreme poverty is high, with a focus on sub-Saharan Africa.

\section{References}

Alves ERA (2012) Embrapa: a successful case of institutional innovation. In: Martha Jr GB, de Souza Ferreira Filho JB (eds) Brazilian agriculture: development and changes. Embrapa, Brasilia, pp 143-160

Arndt C, Jones S, Tarp F (2013) Assessing foreign aid's long-run contribution to growth in development. WIDER Working Paper 2013/072. UNU-WIDER, Helsinki

AQUA (2007) Pioneros en Chile: Con la Acuicultura en las Venas. AQUA (December)

Asian Development Bank (ADB) (2013) Framework of inclusive growth indicators 2013. Asian Development Bank, Manila

Athukorala P-C, Kohpaiboon A (2011) Thailand in global automobile networks. Paper Submitted to Study for the International Trade Center, Geneva

Cabinet Office (2015) Development cooperation charter. Cabinet Officem Tokyo

Cimoli M, Dosi G, Stiglitz JE (eds) (2009) Industrial policy and development: the political economy of capabilities accumulation. Oxford University Press, Toronto

Commission on Growth and Development (2008) The growth report: strategies for sustained growth and inclusive development. World Bank, Washington, DC

Doner RF (1991) Driving a Bargain: automobile industrialization and Japanese firms in Southeast Asia. University of California Press, Berkeley

Easterly W (2002) The elusive quest for growth: economists' adventures and misadventures in the tropics. MIT Press, Cambridge, Mass

Economist (2010) The miracle of the Cerrado. The Economist, August 28

Fujita Y (2011) What makes the Bangladesh Local Government Engineering Department (LGED) so effective? Complementarity between LGED capacity and Donor capacity Development support. JICA Research Institute Working Paper No. 27 (January), pp $1-49$

Greenwald B, Stiglitz JE (2012) Learning and Industrial policy: implications for Africa. Paper presented at new thinking on industrial development: implications for Africa for the International Economic Association

Hosono A (2015) Industrial transformation and quality of growth. In: Haddad L, Kato H, Meisel N (eds) Growth is dead, long live growth: the quality of growth and why it matters. Institute of Development Studies and JICA Research Institute, Sussex and Tokyo, pp 267300

Hosono A (2022) Industrial policies for learning, innovation, and transformation: insights from outstanding experiences. In:Ohno I, Amatsu K, Hosono A (eds) Policy learning for industrial development and the role of development cooperation. JICAOgata Sadako Research Institute for Peace and Development, Tokyo, pp 59-100

Hosono A, Iizuka M, Katz J (eds) (2016a) Chile's Salmon Industry: policy challenges in managing public goods. Springer, Tokyo

Hosono A, Campos CM, da Rocha, Hongo Y (eds) (2016b) Development for sustainable agriculture: the Brazilian Cerrado. Palgrave Macmillan, London

Hosono A, Hamaguchi N, Bojanic A (eds) (2019) Innovation with spatial impact: sustainable development of the Brazilian Cerrado. Springer, Tokyo

Hossain M, Sen B, Sawada Y (2012) Jobs, growth and development: making of the 'other' Bangladesh. In World Development Report 2013 Companion Volume. World Bank, Washington DC, pp 1-53

Inter-American Development Bank (IDB) (2010) The age of productivity: transforming economies from the bottom up. IDB, Washington, DC

Inter-American Development Bank (IDB) (2013) Japan and Latin America and the Caribbean: building a sustainable trans-Pacific relationship. IDB, Washington DC

International Labour Organisation (ILO) (2013) Bangladesh: seeking better employment conditions for better socioeconomic outcomes. ILO, Geneva

Japan Productivity Organization (1990) Singapore productivity improvement project. Japan Productivity Organization, Tokyo

Japan International Cooperation Agency (JICA) (2006) Annual Evaluation Report. JICA, Tokyo

Japan International Cooperation Agency (JICA), International Development Center of Japan (IDJC), The International Development Journal (IDJ) (2010) Data collection survey on strategy formulation on human resources development in Southeast Asia. Final Report. JICA, Tokyo

Japan International Cooperation Agency (JICA), Japan Bank for International Cooperation (JBIC) (2008) Report of the stocktaking work on economic development in Africa and the Asian Growth Experience. JICA, Tokyo

Japan Journal (2014) ODA, Japan's Way. Jpn J (October): 6-13

Kharas H, Makino K, Jung W (2011) Overview: an agenda for the Busan high-level forum on aid effectiveness. In: Karas H, Makino K, Jung W (eds) Catalyzing development: a new vision for aid. Brookings Institution, Washington DC, pp 1-37

Kaushik D (2012) Evolution of industrial landscape in Singapore. Case study presented on the International Society of City and Regional Planning (ISOCARP) 
Congress. http://www.isocarp.net/projects/case_studies/ cases/cs_info.asp?ID=2108

Kuruvilla S, Chua R (2000) How do nations develop skills? Lessons from the skill development experiences of Singapore. Cornell University ILR School, New York. http://digitalcommons.ilr.cornell.edu/cbpubs/8/

Lecler Y (2002) The cluster role in the development of the Thai Car Industry. Int J Urban Reg Res 26(4):799-814

Lin JY (2012) New structural economics: a framework for rethinking development and policy. World Bank, Washington, DC

Maruha-Nichiro Salmon Museum (n.d.) http://www. maruha-nichiro.co.jp/salmon/fishery/09.html

Ministry of Foreign Affairs (MOFA) (2005) Japan's Official Development Assistance (ODA) White Paper 2005. Ministry of Foreign Affairs, Tokyo

Mizobe T (2019) Development of the Cerrado stimulated by the value chain of Soybeans. In: Hosono A, Hamaguchi N, Bojanic A (eds) Innovation with spatial impact: sustainable development of the Brazilian Cerrado. Springer, Tokyo

Mostafa R, Klepper S (2010) Industrial development through tacit knowledge seeding: evidence from the Bangladesh Garment Industry. Working paper, Washington University, St. Louis, MO

Mottaleb KA, Sonobe T (2011) An inquiry into the rapid growth of the Garment Industry in Bangladesh. Discussion paper, National Graduate Institute for Policy Studies (GRIPS)

Natsuda K, Thoburn J (2011) Industrial policy and the development of the automotive industry in Thailand. Working Paper No. 11 (5), Ritsumeikan Center for Asia Pacific Studies (RCAPS)

Noman A, Stiglitz JE (2012) Strategies for African development. In: Noman A et al (eds) Good growth and governance in Africa: rethinking development strategies. Oxford University Press, Oxford, pp 3-47

Organisation for Economic Co-operation and Development (OECD) (2008) Natural resources and pro-poor growth: the economics and politics. OECD, Paris

OECD-DAC (2004) Peer review: Japan. OECD Development Assistance Committee, Paris

Ohno K (2013) Learning to industrialize: from given growth to policy-aided value creation. Routledge, New York

Ohno I, Kitaw D (2011) Productivity movement in Singapore. In: Kaizen National movement: a study of quality and productivity improvement in Asia and Africa. Japan International Cooperation Agency (JICA) and National Graduate Institute for Policy Studies (GRIPS) Development Forum. http://www. grips.ac.jp/forum-e/Kaizen_e.htm

Ohno I, Shimamura M (2007) Managing the development process and aid: East Asian experiences in building central economic agencies. National Graduate Institute for Policy Studies (GRIPS) Development Forum, Tokyo

Rhee YW (1990) The catalyst model of development: lessons from Bangladesh's success with garment exports. World Dev 18(2):333-346
Rodrik D (2007) One economics, many recipes: globalization, institutions, and economic growth. Princeton University Press, Princeton

Sawada Y, Minhaj MM, Kitano N (2018) Economic and social development of Bangladesh: miracle and challenges. Palgrave and Macmillan, London

Schein EH (2001) Strategic pragmatism: the culture of Singapore's economic development board. MIT Press, Cambridge

Shimomura Y (2013) The Japanese view: with particular reference to the shared cognition model in Asia. In: Shimomura Y, Ohashi H (eds) A study of China's foreign aid: an Asian perspective. Palgrave Macmillan, New York, pp 145-168

Shimomura Y, Mieno F (2008) Thailand case study. Aid effectiveness to infrastructure: a comparative study of East Asia and Sub-Saharan Africa. JBICI Res Pap 362(July):1-51

Stiglitz JE, Greenwald B (2014) Creating a learning society: a new approach to growth, development, and social progress. Columbia University Press, New York

Techakanont K (2008) The evolution of automotive clusters and global production network in Thailand. Discussion paper No. 0006, Faculty of Economics, Thammasat University

T. J. (2013) Thailand's booming car industry: Detroit of the east. The Economist, April 4

United Nations Conference on Trade and Development (UNCTAD) (2012) Bangladesh sector-specific investment strategy and action plan: G20 indicators for measuring and maximizing economic value added and job creation from private investment in specific value chain. Pilot Study Results. http://www.unctad.org./ Sections/diae_dir/docs/diae_G20_Bangladesh_en.pdf

United Nations High-Level Panel of Eminent Persons on the Post-2015 Development Agenda (2013) A new global partnership: eradicate poverty and transform economies through sustainable development. United Nations, New York

UNU-WIDER (2014) Aid, growth and employment. Recom Position Paper. UNU-WIDER, Helsinki

World Bank (2012) World development report 2013: jobs. World Bank, Washington, DC

Yamashita S (2004) Development of automobile parts industry and formation of export platform in Thailand (in Japanese). International East Asia Research Center, ASEAN-Auto Project No. 04 (1)

Yunus M, Yamagata T (2012) The Garment Industry in Bangladesh. In: Fukunishi $\mathrm{T}$ (ed) Dynamics of the garment industry in low-income countries: experience of Asia and Africa, pp 1-28. IDE-JETRO Interim Report. http://www.ide.go.jp/Japanese/Publish/Download/ Report/2011/2011_410.html

Yusuf S, Nabeshima K (2012) Some small countries do it better: rapid growth and its causes in Singapore, Finland, and Ireland. World Bank, Washington, DC 


\section{Further Readings}

Bangladesh Garment Manufacturers and Exporters Association (BGMEA) (2013) Trade Information. http:// www.bgmea.com.bd/home/pages/TradeInformation

Hosono A (2010) The Japanese who changed Chile into a Great Salmon-Exporting Country (in Japanese). Diamond Inc., Tokyo

International Labour Organisation (ILO) and Asian Regional Team for Employment Promotion World Employment Programme (1993) Social dimensions of economic reforms in Bangladesh. ILO, Geneva

International Trade Center (2011) Thailand in Global Automobile Networks. http://www.intracen.org/ uploadedFiles/intracenorg/Content/Trade_Support_ Institutions/Business_voice_in_policy_making/WTO_ accession_implication_for_business/Thailand_in_global_ automobile_networks.pdf

Islam Md.Z, Mukhtar U (2011) EPZ history in Bangladesh and its administration and legislation for economic enclave. Bus Manage Rev 1(7):86-102

Iwasaki I (2006) Singapore no Kaihatsu to Good Governance [The Development of Singapore and Good Governance]. In: Shimomura Y (ed) Ajia no Governance [Governance in Asia] (in Japanese). Yuhikaku, Tokyo, pp 159-187

Japan International Cooperation Agency (JICA) (1985) Meghna and Meghna-Gumti Bridge Construction Project Report. JICA, Tokyo

Japan International Cooperation Agency (JICA), Overseas Economic Cooperation Fund (OECF) (2000) IV JICA/OECF joint evaluation: eastern seaboard development program. JICA, Tokyo

Johnson S, Ostry JD, Subramanian A (2007) The prospects for sustained growth in Africa: benchmarking the constraints. NBER Working Paper No. 13120

Kharas H, Makino K, Jung W (eds) (2011) Catalyzing development: a new vision for aid. Brookings Institute, Washington, DC

Open Access This chapter is licensed under the terms of the Creative Commons Attribution-NonCommercialNoDerivatives 4.0 International License (http:// creativecommons.org/licenses/by-nc-nd/4.0/), which permits any noncommercial use, sharing, distribution and reproduction in any medium or format, as long as you give appropriate credit to the original author(s) and the source, provide a link to the Creative Commons license and indicate if you modified the licensed material. You do not have permission under this license to share adapted material derived from this chapter or parts of it.
Kuchiki A (2007) Ajia Sangyou Cluster Ron: flow chart approach no Kano-sei [Industrial clusters in Asia: possibility of flow chart approach] (in Japanese). Shoseki Kobo Hayakawa, Tokyo

Lin JY (2012) The quest for prosperity: how developing economies can take off. Princeton University Press, Princeton

Noman A, Botchwey K, Stein H, Stiglitz JE (eds) (2012) Good growth and governance in Africa: rethinking development strategies. Oxford University Press, Oxford

Schein EH (1999) The corporate culture survival guide. Jossey-Bass, San Francisco

Shimamura M (2007) Building Central Economic Agencies. National Graduate Institute for Policy Studies (GRIPS) Development Forum. http://www.grips.ac.jp/ teacher/oono/hp/course/index.htm

Stiglitz JE (1987) Learning to learn, localized learning and technological progress. In: Dasgupta P, Stoneman $\mathrm{P}$ (eds) Economic policy and technological performance. Cambridge University Press, Cambridge, pp 125-153

Techakanont K (2011) Thailand Automotive Parts Industry. In: Mitsuhiro K (ed) Goods trade in East Asia: economic deepening through FTAs/EPAs. Research Report No. 5. Institute of Developing Economies Bangkok Research Center (IDE-BRC), pp 192-229

Teoh ZW, Sathirathi S, Lam D, Han Lai C, Chareonwongsak K (2007) Thailand automotive cluster. Final paper, Macroeconomics of competitiveness. https:// www.isc.hbs.edu/resources/courses/moc-course-atharvard/Documents/pdf/student-projects/Thailand_ Automotive_2011.pdf

World Bank (2009) World Development Report 2009: reshaping economic geography. World Bank, Washington, DC

The images or other third party material in this chapter are included in the chapter's Creative Commons license, unless indicated otherwise in a credit line to the material. If material is not included in the chapter's Creative Commons license and your intended use is not permitted by statutory regulation or exceeds the permitted use, you will need to obtain permission directly from the copyright holder.

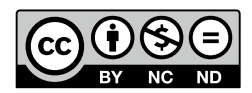

